\title{
WETLANDS AND THEIR FISH DIVERSITY IN ASSAM (INDIA)
}

Devashish KAR *

* Assam (Central) University, Division of Wetlands, Fisheries and Aquaculture, Department of Life Science, Silchar, Assam, India, IN-788011, devashishkar@yahoo.com.

DOI: 10.2478/trser-2019-0019

KEYWORDS: wetlands, habitat, fish, Epizootic Ulcerative Syndrome.

\section{ABSTRACT}

Water is indispensably important for sustenance of life. Wetlands serve as potential reservoirs of water which also harbour coveted bioresources, which sustain animal life. Fish is a potential bioresource for nutrition and offer work places for people. The Asian continent has innumerable wetlands with the Indian sub-continent portraying myriads of wetlands of different kinds, including perennial wetlands (locally called "Beel” or "Taal”), seasonal floodplain wetlands ("Haor") and river-formed oxbow wetlands ("Anua"). In addition to playing a pivotal role in providing nutrition and work places to the people, wetlands also play a significant role in flood management, in regulating biogeochemical cycles, and above all, perhaps, in the rehabilitation of the innumerable fish stocks.

ZUSAMMENFASSUNG: Die Vielfalt der Feuchtgebiete und deren Fischarten in Assam (Indien).

Wasser ist von unentbehrlich für die Erhaltung des Lebens. Die Feuchtgebiete dienen als potentielle Wasserspeicher, die ebenfalls begehrte Bioressourcen beherbergen, die das Leben der Tiere erhalten. Die Fische stellen eine potentielle Bioressource zur Ernährung und beruflichen Betätigung der Bevölkerung dar. Feuchtegebiet finden sich in allen Breiten- und Längen rund um den Erdball. Der asiatische Kontinent umfasst unzählige Feuchtgebiete, wobei sich mit dem indischen Sub-Kontinent Myriaden unterschiedlicher Ausprägungen abzeichnen. Sie reichen von permanenten - lokal als "Beel” oder "Taal" genannten Feuchtgebieten, zeitweilige überfluteten Auen ("Haor") bis hin zu den von Flüssen geschaffenen Altarmen (“Anua”). Zusätzlich zu ihrer grundlegenden Rolle als Nahrungsquelle und berufliche Tätigkeit für die Bevölkerung, spielen die Feuchtgebiete eine signifikante Rolle im Hochwassermanagement, in der Regelung der bio-geochemischen Kreisläufe und vor allem wohl in der Wiederherstellung der unzähligen Fischbestände.

REZUMAT: Diversitatea zonelor umede şi peştii acestora în Assam (India).

Apa este indispensabilă pentru menținerea vieții. Zonele umede servesc drept potențiale rezervoare de stocare a apei, care de asemenea adăpostesc mult solicitatele resurse biologice, asigurând viața animalelor. Peștii constituie o potențială resursă de hrană pentru populație și în același timp le asigură oamenilor și locuri de muncă. Zonele umede sunt răspândite pretutindeni pe glob. Continentul Asiatic adăpostește nenumărate zone umede, în sub-continentul Indiei conturându-se o miriadă de diferite tipuri ale acestora. Sunt incluse zone umede permanente, denumite local „Beel” sau „Taal”, zone umede temporare, reprezentate de luncile inundabile („Haor”) precum şi brațe moarte create de dinamica râurilor. În afară de rolul lor de bază ca sursă de nutriție pentru populație și ofertă de locuri de muncă, zonele umede joacă un rol important în managementul apelor mari, în reglarea circuitelor biogeochimice și în primul rând se pare în refacerea nenumăratelor stocuri de pești. 


\section{INTRODUCTION}

Life is water; water is life (Schopf and William, 2002; Steel et al., 2010). Many significant human civilisations and cultures, had made their beginning near the water, including wetlands (Wells, 1922; Bănăduc et al., 2016). These highlight the indispensability of water, which is very broadly classified into two categories based on the type of water bodies. These are, (i) the standing water or the "lentic" water; and, (ii) the running water or the "lotic" water. In this regard, it may be mentioned here that, although the name is "standing water", actually, the water in such bodies is in motion in different ways. Hence, "standing water" does not necessarily mean "static". It simply means that the water does not flow. (Kar, 1990, 2007a, 2013a)

Of late, some scientists believe the lakes to be much the same wherever they occur because similarities are often found among the different lakes with regard to water colour, taste, hardness and aquatic biota (Kar, 1990, 2007a, 2013a). Although a partial survival of this idea is still prevalent among many laymen, with the advent of limnological science, it has been established that lakes as a class manifest most amazing physical, chemical and biological diversity (Kar, 1990, 2007a, 2013a). Further, as a partial indication of lake diversity, it could well be stated that lakes are large, medium or small; deep or shallow; protected or unprotected; with or without tributaries and outlets; fresh, brackish or salty; acidic, neutral or alkaline; hard, medium or soft; turbid or clear; surrounded by bogs, swamps, forest or open shore; high or low in dissolved content; with or without stagnant zones; with marl, muck, sand or clay bottoms; with or without vegetation beds; with high, medium or low biological productivity; young, mature or senescent; etc. Kar, 2013a). However, many intergrades within the various groups of features mentioned above exist. The amazing lake diversity is the effect of multitudinous combinations of many of these characteristics mentioned above. (Kar, 2007a, 2013a).

Some works done and a survey of literature available in the aspects of limnology, wetlands, fish and fish disease (with emphasis on Epizootic Ulcerative Syndrome/EUS), are as follows: APHA, 1995; Banerjea, 1967; Barbhuiya et al., 1999, 2006, 2007a, b; Barhoi et al., 2015; Bimola et al., 2014, 2015a, b, 2016; Battish, 1992; Bennet, 1962; Biswas and Calder, 1955, 1984, Callinan et al., 1996; CAMP, 1998; Chaudhuri, 1960; Choudhury et al., 2017a, b; Chinabut et al., 1995; Chumley, 1910; Cook, 1977; Das and Kar, 2011; Das et al., 2013; Das and Kar, 2013, 2016a, b, c; Das et al., 2018; Das and Kar, 2013, 2014, 2016a, b, c, d; Das et al., 2018; Day, 1873, 1878, 1885, 1889; Devi et al., 2017; Dey, 1973, 1981; Dey and Kar, 1985, 1987, 1989a, b, c, d, 1990, 1994; Dhar, 2004; Dhar et al., 2004; Dutta et al., 2017; Dutta et al., 2014; FAO, 1963, 1974, 1986; Fernando and Furtado, 1975; Forel, 1892-1904, 1895, 1901; Fraser et al., 1992; Frerichs et al., 1986; Fritsch, 1965; Gadgil and Kar, 2000; Ghosh and Lipton, 1982; Gopal et al., 1981; Gunther, 1880; Hamilton, 1822; Hickling, 1971; Henderson and Markland, 1987; Hooker, 1872; Hora, 1953; Hora and Menon, 1952; Hora and Silas, 1952; Hugueny and Paugy, 1995; Hutchinson, 1939, 1967, 1975; Jackson, 1973; Jayaram, 1981, 1999, 2003; Jhingran, 1991; Kar, 1984, 1985, 1990, 1996, 1999a, b, 2000a, b, 2002, 2003a, b, c, 2005, 2006a, b, 2007a, b, 2010a, b, c, 2011a, b, 2012a, b, c, 2013a, b, 2014a, b, c, 2015, 2016a, b); Kar and Barbhuiya, 2000a, b, c, d, 2001, 2002a, b, c, 2004, 2008, 2013; Kar and Dey, 1982a, b, 1986, 1987, 1988a, b, c, d, 1990a, b, c, d, e, 1993, 1995, 1996, 2000a, b, c, 2002; Kar and Sen, 2007; Kar and Upadhyaya, 1998; Kar et al., 1990, 1993, 1994a, b, 1995a, b, c, d, e, 1996a, b, c, d, e, 1997, 1998a, b, c, 1999a, b, c, 2000a, b, c, d, e, 2002, 2003a, b, 2006a, b, 2007a, b, c, 2008a, b, c, 2009, 2010, 2014, 2015; Kar and Kar, 2013, 2014, 2016a, b, c, d, e, f; Kar et al., 2017, 2018; Laskar et al., 2002, 2017; Le Cren, 1951; Lilley et al., 1997; Menon, 1955, 1973, 1974, 1988, 1994, 1999; Misra, 1976; Mookerjee, 1945; Motwani et al., 1962; Moyle, 1976; Narzary et al., 2015; Nath and Dey, 2000; Nautiyal and Lal, 
1981; Ogale, 1994; Pearsall, 1938; Pennak, 1953; Pillay and Ghosh, 1958; Riji et al., 2016; Roberts, 1978; Roberts et al., 1992; Sarwar et al., 2016; Sehgal, 1994; Sen, 1982, 1985, 2000; Shaw and Shebbeare, 1937; Silas, 1952; Singh et al., 2013, 2015a, b, c; Southwell and Prashad, 1918; Swingle, 1950; Smith, 1950; Sonowal et al., 2015; Sreenivasan, 1968; Talwar and Jhingran, 1991; Toham and Tuegels, 1998; Umi et al., 2015; Vaas and Schurman, 1949; Welch, 1935, 2003; Wetzel, 1983; Zutshi et al., 1970.

\section{MATERIAL AND METHODS}

Fish samples were collected through fishing using caste nets (diameter 3.7-1.0 m), gill nets (vertical height 1.0-1.5 m; length 100-150 m), drag nets (vertical height 2.0 m), triangular scoop nets (vertical height $1.0 \mathrm{~m}$ ) and a variety of traps. Camouflaging technique was also used to catch the fishes, whenever necessary. Fishes have been preserved at first in undiluted formaldehyde in the field itself and then in $10 \%$ formalin solution in the laboratory. Fishes have been identified based on standard literature (Day, 1878, 1889; Shaw and Shebbeare, 1937; Menon, 1974, 1999; Talwar and Jhingran, 1991; Jayaram (1981, 1999, 2010). Yield statistics were extrapolated (Kar, 1990; Dey and Kar, 1990) from daily catch statistics recorded at the fish landing centres (FAO, 1974); while, the trend and cyclic variations were constructed through application of 12 months moving average method (Coxton and Cowden, 1950; Kar, 1990; Dey and Kar, 1990; Kar and Dey, 2000a, b). Physico-chemical characteristics of water were estimated based on standard methods (APHA, 1995).

"Wetlands" are "wet-lands", where the soil is saturated with water for sometime during the year. According to IUCN (1970), wetlands are areas of marsh, fen, etc., temporary or permanent; natural or artificial mass of water, the depth of which generally does not exceed six m. Wetlands are areas which contain substantial amount of standing water with little flow.

Wetlands in North-East India. The North-Eastern (NE) region of India, a typically difficult topography with undulating terrains and enormous amount of water resources represented by intricate network of articulating rivers and associated wetlands containing a bewildering diversity of aquatic biota, perhaps, unparalleled in the history of the world; thus, acquiring its designation as a "hotspot" of biodiversity (WCMC, 1998). However, the region certainly provides enough potential for fish production which could supplement food requirement for the region and respond to the diminishing protein supply (Kar, 2007a).

Wetlands in Assam. Besides lotic territories, the lentic water bodies of $0.72 \times 10^{6}$ ha lake coverage in India have great fishery potential. NE region, in general, and Assam, in particular, is blessed with a number of lentic systems, locally called Beel, Haor, Anua, Hola, Doloni, Jalah, etc., which alone constitute around $81 \%$ of the total lentic area $\left(0.12 \times 10^{6} \mathrm{ha}\right)$ in Assam. These lentic systems are generally shallow and open, with a size from 35 to 3458.12 ha and a depth from 0.25 to three metres (in some, however, the maximum depth may exceed six $\mathrm{m}$ ) at full storage level (FSL). Further, in Assam, there are around 1,392 wetlands having a total of around 22,896 fisheries of different categories, out of which, the number of registered wetlands is only 394 (30.38\%) covering an area of around 70,000 ha. Of them, around 19,000 ha are considered in good condition, around 15,000 ha are in semi-derelict condition, and around 35,000 ha are in derelict condition (Government of Assam, 2006). Assam is rich in wetlands, which are located in wildlife sanctuaries, national parks and even in Biosphere reserve areas. Some are Ramsar sites that need to be addressed. 
Classification of wetlands in Assam. Wetlands occur throughout the globe in almost all climatic zones and are said to cover around 6\% of the earth's surface. One of the simplest classification of wetlands has been provided by IUCN's Ramsar Convention (2004), which is briefly as follows: freshwater lakes/wetlands, oxbow lakes/wetlands, FW (freshwater) ponds, marshes, swamps, bogs, and reservoirs.

In the tropical areas, notably, in the Indian subcontinent, and particularly, in Assam region and adjoining places as Bangladesh, wetlands are usually shallow depressions which could normally be in the form of a basin at the centre of hillocks on all sides; or, could be an abandoned segment of a river (oxbow wetland); or, could be a shallow portion of a river course which may be detached from the main river course during the dry season. Sometimes, wetlands in NE India could be originally formed due to tectonic activities (Kar et al., 1996b; Kar, 2007a, b).

In the Assam region, and also in the adjoining Tripura and Bangladesh regions, three main categories of wetlands can be commonly found. They are regionally known as follows (Kar, 2007a, 2013a): (a) "Beel”: perennial wetlands, which contain water throughout the year; (b) "Hoar": seasonal wetlands which contain water for some period of the year only, particularly, during the rainy season; as such, they are also called "floodplain wetlands"; (c) "Anua": these are peculiar river-formed perennial oxbow-type wetlands, which are generally formed due to changes in the river course and which may or may not retain a connection with the original river.

Limnological study of the wetlands in Barak drainage of Assam. Information on the hydrobiological conditions of any water body is considered of prime necessity before endeavouring to utilize it as a productive fishery. It is an established fact that proper planning depends on the availability of reliable data. But, in the limnological and fisheries sector, there is need for more such information for the North-Eastern region of India in order to get a holistic view (Kar, 1990, 2007a, 2013a).

Contrary to such specific background, the naturally-formed lakes and rivers constitute great potential of fishery resource in the Indian sub-continent. Many wetlands are still unregistered and under the control of both government and private sectors. In this context, it is interesting to note that the district of Cachar includes the highest number of unregistered wetlands in Assam (Dey, 1981; Kar and Barbhuiya, 2000a, b, c, d; 2001, 2002a, b, c; 2004).

Notwithstanding the above, some of the significant lentic systems (wetlands) in the Barak Valley area $\left(92^{\circ} 15^{\prime}\right.$ to $93^{\circ} 15^{\prime} \mathrm{E}$ and $24^{\circ} 10^{\prime}$ to $25^{\circ} 10^{\prime} \mathrm{N}$ ) located in Assam are briefly listed below:

(i) Beel (perennial wetland): Sone Beel (the biggest, 3458.12 ha at FSL), Rata Beel, Sagar Beel, Rani-Meghna Beel, Angang Beel, Medha Beel, Duberi Beel, Auti-Bauti Beel, Narapati Beel, Jabhda Beel, Karkari -Jonamara Beel, Petua Beel, Atoa Beel, Lora Beel, Bishali Beel, Gudi Beel, Chhatradharia Beel, Mahishatal Beel Deochhara Beel, Ashihali Beel, Dhalchhara Beel, Hatichhara Beel, Doloo Beel, Sat Beel, etc.

(ii) Haor (seasonal floodplain wetland): Chatla Haor, Bakri Haor, Puneer Haor, etc.

(iii) Anua (river-formed oxbow wetland): Baskandi Anua, Rupairbala Anua, Dungripar-Kaptanpur Anua, Satkarakandi Anua, Ram Nagar Anua, Baraknadi-Salchapra Anua, Fulbari Anua, Sibnarayanpur Anua, Chiri Anua, Rukni Anua, etc.

Barak Valley is rich in biodiversity, where Brark River, a left bank tributary of Brahmaputra flows. 
Fish samples. Fish samples were collected through fishing using cast nets (diameter 3.7-1.0 m), gill nets (vertical height 1.0-1.5 m; length 100-150 m), drag nets (vertical height $2.0 \mathrm{~m}$ ), triangular scoop nets (vertical height $1.0 \mathrm{~m}$ ) and a variety of traps. Camouflaging technique was also used to catch the fish, whenever necessary. Fish samples were preserved in undiluted formaldehyde in the field and then in $40 \%$ formalin in the laboratory. Fish were identified after consulting standard literature (Day, 1878, 1889; Shaw and Shebbeare, 1937; Menon, 1974, 1999; Talwar and Jhingran, 1991; Jayaram (1981, 1999, 2010). Yield statistics were extrapolated (Kar, 1990; Dey and Kar, 1990) from daily catch statistics recorded at the fish landing centres (FAO, 1974); while, the trend and cyclic variations were constructed through application of 12 months moving average method (Coxton and Cowden, 1950; Kar, 1990; Dey and Kar, 1990; Kar and Dey, 2000a, b).

Environmental parameters. The following water parameters: turbidity, temperature, hydrogen-ion-concentration, dissolved oxygen (DO), free carbon di-oxide $\left(\mathrm{FCO}_{2}\right)$, total alkalinity (TA) and specific conductivity (SC), as well as the silt load were studied.

\section{RESULTS AND DISCUSSION}

Some of the significant lentic systems (wetlands) in the Barak Valley Region (92 ${ }^{\circ} 15^{\prime}$ to $93^{\circ} 15^{\prime} \mathrm{E}$ and $24^{\circ} 10^{\prime}$ to $25^{\circ} 10^{\prime} \mathrm{N}$ ) of Assam are discussed below.

Geology. This region is geologically unique because the processes of morphogeny, lithogeny and tectonics are said to be active simultaneously. The Barak River basin has been formed by two geotectonic features, (a) the Nagaland-Haflong-Diyung in the north and (b) the ophiolite belt of Nagaland and Manipur in the east (across the Manipur Valley). This stronglyfolded mobile belt is separated by the northern thrust boundary from the Assam Platform, which is said to carry sedimentary cover of the same age. In fact, the ophiolite belt separates the zone from the Myanmarese Platform. The ophiolite probably represents the margin of the Indian Plate. It has perhaps continued southward into the Andaman and Nicobar islands through the Arakan Yoma (around Myanmar) and then into the Indonesian chain of islands. In the folded belt, this stage is believed to have passed long ago and the prevalent model of evolution envisages the formation of folded mountain of the subduction margin. As the rising mountain is believed to have pushed back the sea, the next zone to the west has been similarly folded and uplifted. Thus, a progressive migration of orogeny, morphogeny and sedimentation is seen. The area is said to be totally land now and probably remains dynamically active and the direction of evolution is perhaps the same (Kar, 2013a).

\section{Sone Beel}

It is situated between $92^{\circ} 24^{\prime} 50^{\prime \prime}$ to $92^{\circ} 28^{\prime} 25^{\prime \prime} \mathrm{E}$ and $24^{\circ} 36^{\prime} 40^{\prime \prime}$ to $24^{\circ} 44^{\prime} 30^{\prime \prime} \mathrm{N}$ within Karimganj District of Assam and falls in a syncline (Fig. 1) (Kar, 1990, 2007, 2013).

The physiography of the district is said to consist of small hillocks intervened by wide low valleys. The hillocks possess NE-SW and NE-SSW trend near the Barail range and N-S trend towards south away from the Barail range. Incidentally, Sone Beel, the biggest "Beel" (wetland) in Assam, is situated in between two hill ranges, namely, the Badarpur-Saraspur range and the Chowkirmukh-Dohalia range. In the east, the neighbouring structure is the Badarpur line of folding; while, there is the Chargola anticline towards the west. A typical geomorphological feature is the tightfoldedness of the anticlines represented by hillocks having very high dips of the sedimentary beds (Kar, 1990, 2007a, 2013a; Kar et al., 1999a). 
Information obtained from ONGC and GSI (personal communication Nandi P. K.) reveal that Cachar represents a type area of Surma sediments exhibiting only Tertiary deposits (70 million years). Studies into the rock samples of this wetland have revealed that the hillocks around the wetland are probably formed after Tipam sedimentation. Most of the wetlands in this region, including the mighty Sone Beel, might have been originated after the Dupitila sedimentation during the Mio-Pliocene period (Kar et al., 2003a, b; Kar, 2007a, 2013a).

Around Sone Beel, the soil in the catchment of the plains is generally loamy but occasionally sandy or gravelly admixed with quartz. On the other hand, the hilly portion of the catchment consists generally of fine grain sand stones bearing many angiosperms and, thus, forms the evergreen forest.

The principal feeder of the wetland is the major inflow, the Singla River, which drains a total catchment area of around 46,105 ha. In addition, the wetland receives water from 12 minor inlets and many other canals flowing from both hills and plains, all of which together drain a total of around 18,941.9 ha of the catchment area of the wetland. Out of this, around 11,003.9 ha lies in the plains, while, around 7,938.0 ha falls in the hilly portion of the wetland. These form $58.09 \%$ and $41.91 \%$, respectively, of the total catchment area of the wetland (Kar, 2013a; Kar and Dey, 1986, 1987, 1988).

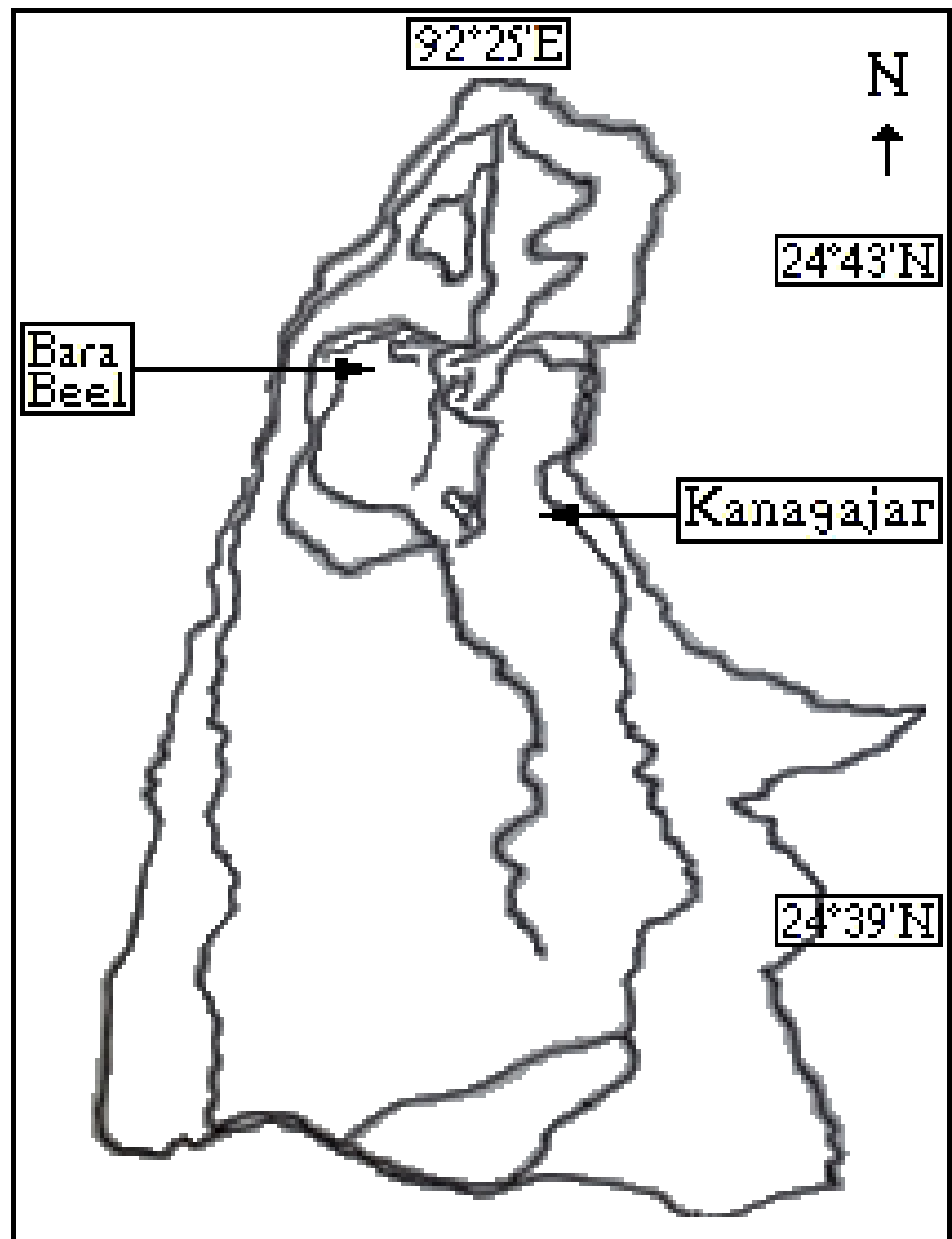

Figure 1: Boundary contour map of Sone Beel Wetland at full storage and dead storage levels. 
The catchment of the wetland also includes the reserved forests of the province, notably, the Singla Reserve Forest (RF). During monsoon, the wetland receives some humic, as well as inorganic and organic nutrients from the hillocks and cultivable areas, particularly around the swollen tail end of the wetland.

The maximum length (L) and breadth (B) of the wetland at full storage level (FSL) were measured as $12.5 \mathrm{~km}$ and $3.9 \mathrm{~km}$ respectively. These values were reduced to $4.07 \mathrm{~km}$ and $2.22 \mathrm{~km}$, respectively, at its dead storage level (DSL).

The area of Sone Beel at FSL was measured as 3458.12 ha, while at DSL, the area diminished to only $409.37 \mathrm{ha}$. The length of the shoreline was measured as $35.4 \mathrm{~km}$ while the shore and volume developments were recorded as 1.69 and 0.15 , respectively, with a mean depth of $0.29 \mathrm{~m}$. The gross volume of the wetland was found to be $101.54 \times 10^{6} \mathrm{~m}^{3}$.

Silt islands (SI) were recorded in the north and south of the wetland. The Gopikanagar SI (area 3.74 ha and $25 \mathrm{~m}$ above the sea level/MSL) and Khagdi Tila SI (area 3.31 ha and 21 MSL) were noteworthy. Interestingly, the wetland surface itself is situated $23 \mathrm{~m}$ (MSL).

The wetland basin tended to become deeper from south to north. The contours in the west were found to be almost parallel and closer than their counterparts in the east (Fig. 2).

Notwithstanding the above, the wetland exhibited variable water level ranging from 0.07 to $6.0 \mathrm{~m}$ at FSL (June-September) and 0.02 to $2.08 \mathrm{~m}$ at DSL (November-April). The average depth of the wetland was found to vary from $0.16 \mathrm{~m}$ to $3.38 \mathrm{~m}$.

The wetland is mainly fed with the major inlet, the Singla River; although, 12 minor inlets were found to exist in different parts of the wetland. The Singla River originates as “Thing Tlawng Lui” at an altitude of around 365.21 m MSL in Mizo Hills, from where, after traversing a meander course of around $62.75 \mathrm{~km}$, it enters Sone Beel.

The major outflow (there being no minor outflow) of the wetland, the Kachua River originates from the northern most end of the wetland. It drains out the wetland water into the mighty Kushiara River (a tributary of the Barak River) after covering a length of around 19.30 $\mathrm{km}$. Although, the Kachua River was blocked by a blind dam constructed by the Government of Assam in 1950-1951, the dam was replaced by a lock gate in 1964 after experiencing navigational and fishery problems. Consequently, studies revealed pouring-in of $350.0 \mathrm{mg} / \mathrm{L}$ of silt into the Sone Beel by the inlet Singla River; and, concomitantly, expulsion $88.1 \mathrm{mg} / \mathrm{L}$ of silt by the outlet Kachua River from Sone Beel.

An attempt was made in the present study to reflect the change detection of boundary contour of Sone Beel wetland in Assam on a GIS Platform, using PCI Geomatica version 10.1 by comparing the ground map (prepared through standard survey, Kar, 1990, 2007a, 2013a) with Georeferenced Survey of India Topomap and superimposing the LISS IV Satellite imageries data of 2006 over a period spanning from 1880, 1980 to 2006 (Figs. 1 and 4). Orange coloured region depicts the area for the year 1880, which is around 6,774 ha. Blue colour depicts the area for the year 1980, which is around 3,234.4 ha, while red coloured region depicts the area for the year 2006, which is around 392.4 ha. The latter contour was prepared in winter season, while the other two contours were made during rainy season. So, within a span of around 100 years from 1880 to 1980, there was a shrinkage of around 3,539.6 ha of the water spread area. Extensive deforestation coupled with soil erosion has led to large scale siltation of water bodies, thus, causing shrinkage in the water spread area. One could expect further diminution in the water spread area due to the siltation process, if it continues. 


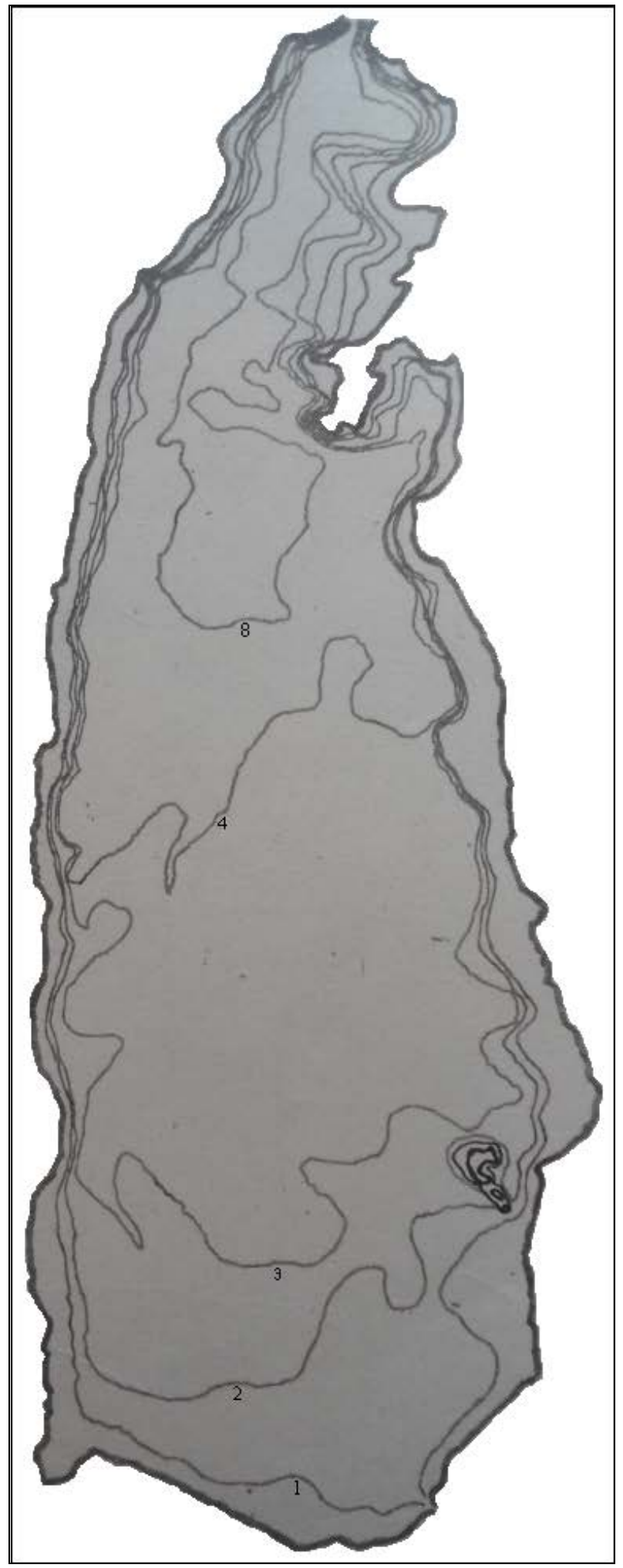

Figure 2: Depth contour map of Sone Beel Lake during live storage level. (contour at one meter intervals). 


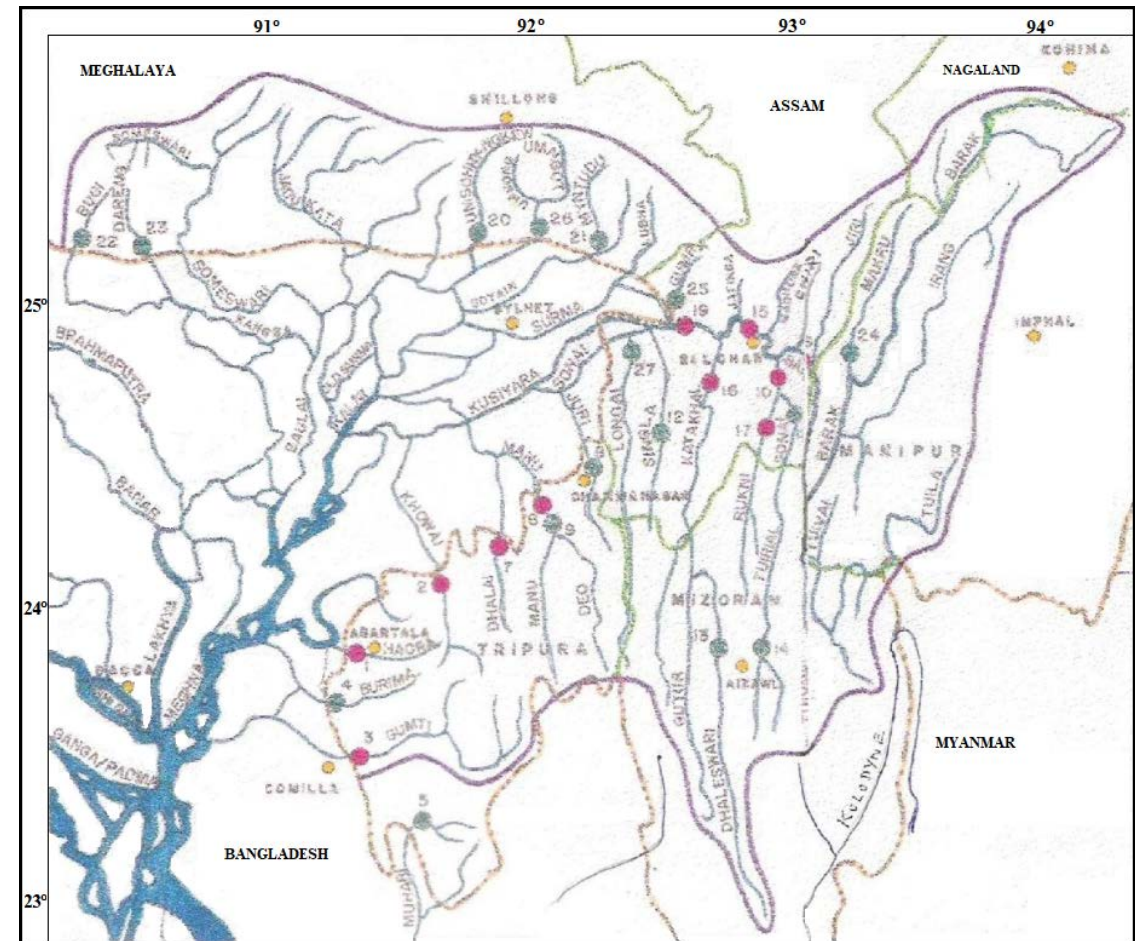

Figure 3: Riverine Network of North-East India; spots colour: blue - water bodies, red - sampling points, yellow - names of places.

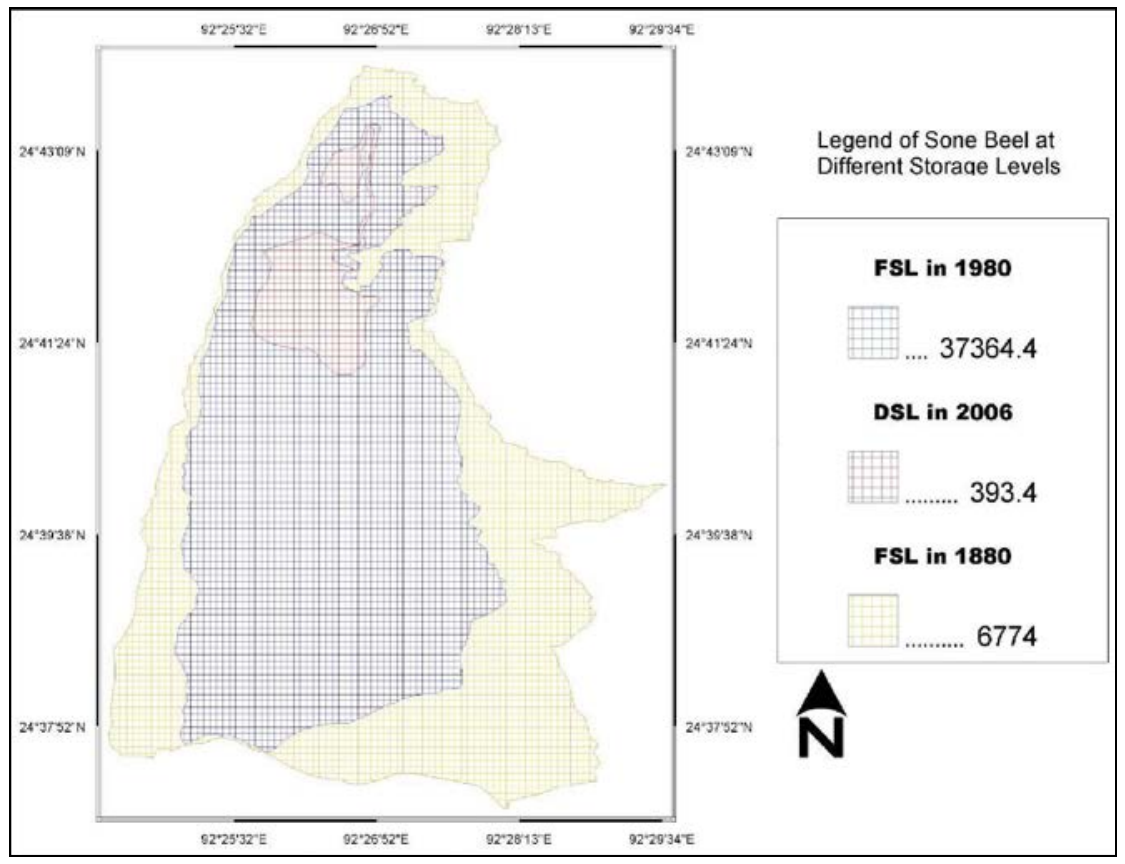

Figure 4: Georeferenced map of Sone Beel,

showing detected changes in the wetland from 1880, 1980 to 2006. 


\section{Physico-chemical characteristics of water of Sone Beel}

In Sone Beel wetland, the water was found to exhibit interesting trend in its physico-chemical features. The silt load of the inlet water measured at the Beel mouth was found to vary from 27 to $350 \mathrm{mg} / \mathrm{L}$. Concomitantly, the silt load values of the outlet water was found to fluctuate from 9.0 to $88.1 \mathrm{mg} / \mathrm{L}$. The overall result indicated that more amount of silt is retained and deposited in the Beel and lesser amount is expelled through the outlet, thereby, resulting in overall siltation of the Beel (Kar, 1990; Dey and Kar, 1987). The fluctuation trend of water temperature was usually almost constant, with high values during the warm season followed by low values during the cold months. Conversely, low $\mathrm{pH}$ values were usually recorded during the monsoon period and higher values during the postmonsoon days.

Concomitantly, low values of DO were observed during rainy days, while higher trend was found in the dry days, exhibiting more or less an identical trend at varying depth levels. The saturation of DO was found to vary from $35.42 \%$ to $70.40 \%$ at the surface and from $32.34 \%$ to $70.31 \%$ at the bottom levels. Further, higher values of $\mathrm{FCO}_{2}$ were generally found during the rains but lower values during the post-monsoon days. In addition, higher values of TA were usually recorded during the dry season while lower values during the rainy season. Higher values of conductivity were sometimes recorded at certain spots around fish landing centres.

\section{Physico-chemical characteristics of soil of Sone Beel}

The values of various physico-chemical characteristics of soil of Sone Beel in Assam are as follows (Kar, 1990): temperature $\left({ }^{\circ} \mathrm{C}\right)$ : $19.9-32.3$; pH: 5.09 - 5.99; conductivity ( $\mu \mathrm{mhos} / \mathrm{cm}$ at $25^{\circ} \mathrm{C}$ ): 47.42 - 322.08; organic carbon (\%): $0.25-1.74$; available phosphorus (mg/100 g): 0.15 - 1.93; and available potassium (mg/100 g): 1.6 - 24.8.

\section{Plankton communities of Sone Beel}

A total of 47 different forms of phytoplankton belonging to five groups have been recorded in Sone Beel. Of these, the Chrysophyta include the maximum number and Pyrrophyta, the least. The phytoplankton density in the Beel varies from 48 to 5,308 (average 1,027) units/liter. The minimum population is generally recorded during the rainy season and the maximum during the dry season. The cyanophytes and the euglenophytes generally exhibit prolific growth during the spring and summer with occasional abundance during monsoon. The Chlorophytes usually show higher occurrence intensity during summer and early monsoon with infrequent richness during winter and spring. The Chrysophytes are generally recorded throughout the year. The Pyrrophytes are found mainly during the autumn.

Nineteen different forms of zooplankton, belonging to five groups have been recorded till date in Sone Beel (Michael and Sharma, 1988). The zooplankton density varies from six to 380 (average 49) units/liters. Low density is generally recorded during February-March and high density during November-December. In Sone Beel, a considerable portion of zooplankton population has succumbed to the day-in and day-out fishing operations; thus, leading to their poor population in the Beel. Nevertheless, the copepods have been found to occur throughout the year. On the other hand, the rotifers are quite abundant mainly during the early monsoon and autumn. However, the cladocerans are generally abundant during autumn and winter (Kar, 1990; Dey and Kar, 1994). 


\section{An account of aquatic macrophytes (AM) of Sone Beel}

Aquatic macrophytes exhibit a heterogeneous assemblage of 23 species. The important AM species are given below (Dey and Kar, 1989a; Kar, 1990, 2007a, 2013a): Alternanthera sessilis, Azolla pinnata, Cynodon dactylon, Echinochloa stagnina, Eichhornia crassipes, Eleocharis acutangula, Euryale ferox, Hydrilla verticillata, Hygrorhiza aristata, Ipomoea aquatic, Justicia repens, Nechamandra alternifolia, Nymphaea nouchali, Nymphoides cristata, Nymphoides indica, Oryza sativa, Polygonum flaccidum, Sagittaria trifolia, Salvinia cucullata, Scirpus sp., Trapa bispinosa, Vallisneria spiralis, and Vetiveria zizanoides.

The biomass of AM varies from 0.58 to $21.90 \mathrm{~kg} / \mathrm{m}^{2}$ (average $2.48 \pm 0.82$ ), maximum in December and minimum in May. In addition to water level (WL) and amplitude of flooding (Welcomme, 1979), the growth and distribution of the AM is influenced by the water quality.

Eichhornia crassipes has been the sole perennial species in the wetland, followed by $H$. verticillata and T. bispinosa, occurring during most of the months of the year. During dry season, the emergent varieties (e.g. E. stagnina, E. acutangula, S. eriophorum, O. sativa, S. trifolia and $P$. flaccidum) and the submerged types (e.g. $H$. verticillata, $V$. spiralis) generally succeed, flourish and show high abundance at less WL when the wetland exhibits a decreasing trend in its depth. It indicates an indirect relation of AM biomass with WL $(r=-0.130 \pm$ 0.442. $P>0.05$ ) during this period. Higher ranges of conductivity at this time have been found to sustain a rich biomass of the floating T. bispinosa (Pearshall, 1938).

The wetland water during dry season in general portrays high DO produced by photosynthesis at rich insolation, in which $\mathrm{FCO}_{2}$ is consumed and shows a fall. Concomitantly, a direct relationship of AM biomass with DO $(r=0.500 \pm 0.340, P<0.05)$ and an inverse with $\mathrm{FCO}_{2}(r=-0.780 \pm 0.178, P<0.05)$ is recorded. The $\mathrm{pH}$ and TA, which are found to depict rise, portray their direct relationship $(r=0.850 \pm 0.126, P<0.05 ; r=0.022 \pm 0.454, P<0.05)$ with AM biomass. $H$. verticillata and $V$. spiralis, as indicated earlier, are found to be closely $(P<0.05)$ associated during this period $\left(\chi^{2}, 34.67\right)$. Also, a close $(P<0.05)$ association between floating $T$. bispinosa and submerged $V$. spiralis $\left(\chi^{2}, 24.15\right)$ and between submerged $H$. verticillata and emergent $S$. eriophorum $\left(\chi^{2}, 31.89\right)$ is discernible.

With the onset of monsoon, the floating varieties, $N$. nouchali, $N$. cristatum and $N$. indicum occur in their flowering stage. Most of the emergent varieties encountered during winter, spring and summer, get submerged and undergo decay during monsoon. The littoral and the sub-littoral zones of the Beel during monsoon are moderately infested with emergent $C$. dactylon and $V$. zizanoides. $H$. verticillata is sometimes found among submerged varieties. Onset of monsoon, as stated earlier, cause decay of AM, thus, rendering poor AM biomass with corresponding low $\mathrm{DO}, \mathrm{pH}$ and TA but high $\mathrm{FCO}_{2}$ during the periods. Concomitantly, a direct relation of AM with DO $(r=0.940 \pm 0.053, P<0.05)$, $\mathrm{pH}(r=0.160 \pm 0.443, P>0.05)$ and TA $(r=0.530 \pm 0.320, P<0.05)$ have been recorded. Significant $(P<0.05)$ phyto-social association between $C$. dactylon and E. crassipes $\left(\chi^{2}, 12.44\right)$, C. dactylon and $N$. indicum $\left(\chi^{2}\right.$, $10.21), H$. aristata and E. crassipes $\left(\chi^{2}, 13.87\right), H$. aristata and $N$. cristatum $\left(\chi^{2}, 18.96\right)$ are recorded during this season. However, none of the AM species has formed significant phytosocial relation with $E$. ferox, possibly, due to its thorny body, and, the latter, thus, forms a monospecific unit. High species diversity among the AM species is evident in this wetland. And, the level in Sone Beel is found to be high (biased estimate of $H^{\prime}=2.015$; expected value, $E\left(H^{\prime}\right)=2.014$; variance of $\left.H^{\prime}=1.431 E-3\right)$ (Dey and Kar, 1989a). 
Sat Beel. This wetland is situated in the village of Rongpur of Silchar sub-division in Cachar District of Assam. This Beel is an aggregation of seven wetland units located closely to each other and they become a single sheet of water during monsoon.

The physiography of the locality consists mainly of plain land with a small forest along the right bank of Barak River. The seven wetland units, of which Sat Beel is constituted, are Gajaria, Chepta, Bardoloo, Kachudaram, Mokachakri, Koia, and Kejua. The Barak River, which flows around one km away from the Beel, has diverted its original course by around two $\mathrm{km}$ during the last 30 years due to erosion of soil in its right bank. Sat Beel is situated at around $25 \mathrm{~m}$ MSL. The geology is mostly Tertiary formation and is generally fertile clayey loam. Dihing series beds are exposed near the Madhura River which flows also near the Sat Beel (Kar, 2007a).

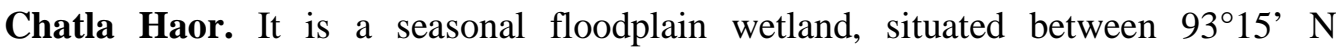
and $24^{\circ} 10^{\prime} \mathrm{E}$ in the Cachar District of Assam. It was considered a "Beel” (perennial wetland) some decades ago having its water spread area reaching Silchar Town. Due to gradual siltation and eutrophication occurring naturally in the succession process, accelerated by human interference, today it has become a "Haor" (seasonal wetland) and retains water for approximately six months in a year having practically no dead storage level (DSL). So, it is almost completely dry during the winter. Having a water spread area of around 1,600 ha at the FSL, Chatla is considered as one of the biggest "Haor" in Assam.

Around Chatla, the soil in the catchment is generally sandy-loam, but shore vegetation is thin. The Haor is drained by a number of small inlets (Jalengachhara, Baluchhara, Salganga) and an outlet (Ghagra River), which drains itself into the Barak River. The catchment of the Haor includes a small portion of the Innerline Reserve Forest. During monsoon, the Chatla, like other similar wetlands, receive some humic as well as inorganic and organic nutrients from the hillocks and surrounding cultivable lands.

The maximum length (L), breadth (B), depth (D) and water spread area (A) of the wetland at FSL have been measured to be $10 \mathrm{~km}, 2.5 \mathrm{~km}, 5.5 \mathrm{~m}$ and 1,600 ha, respectively. Prominent Silt Islands (SI), namely, Bairagitila and Harintila have been found to occur towards the eastern shore of the Haor. Other small Sis, namely, Haltia, Diblia, and Barshangan, occur towards the SW side of the Haor.

Among the inlets, the Salgonga River originates from the foot hills of the Mizo Hill range, while the Jalengachhara and Baluchhara, which are mostly rheophilic in nature, flow down into the Haor from the Innerline Reserve Forest. The only major outlet, the Ghagra River, drains the water of the Haor directly into the Barak River traversing a tortuous course of around $14 \mathrm{~km}$ from the northern boundary of the Haor (Kar, 2007).

Physico-chemical characteristics of water of Chatla Haor. The values of the measured water quality parameters are as follows (Kar, 2007): water temperature: $33^{\circ} \mathrm{C}$; turbidity: $83.27 \mathrm{NTU}$; pH: 6.09; $\mathrm{FCO}_{2}$ : $7.59 \mathrm{mg} / \mathrm{L}$; TA: $83.39 \mathrm{mg} / \mathrm{L}$; conductivity: 142.91 $\mu \mathrm{mhos} / \mathrm{cm}$.

An account of zooplankton of Chatla Haor. Studies done in the around 1,600 ha Chatla Haor in Cachar District have revealed the occurrence of 18 species of zooplankton consisting of two species each of Protozoa and Copepoda, six species of Rotifera and eight species of Cladocera. The occurrence of Arcella sp. among the protozoans and this of Brachionus calyciflorus among the rotifers probably indicate eutrophic conditions in the wetland. Two protozoans, namely, Arcella sp. and Paramoecium sp., represent $11.11 \%$ of the total zooplankton taxa in the wetland. Verma 
and Dalela (1975) report Arcella sp. from eutrophic waters. Six rotifers constituting around $33.33 \%$ of the total zooplankton taxa have been also identified, of which, Filinia sp. and Lecane sp. are found to be abundant. The identified copepods include Cyclops sp. and Diaptomus sp., which represent around $11.11 \%$ of the total zooplankton taxa. The total zooplankton count in this case is found to be $68 \pm 45$ units/litre (Kar and Barbhuiya, 2004).

An account of the aquatic macrophytes (AM) of Chatla Haor. A total number of 23 species of AM have been recorded in the area of 1,600 ha (at FSL) of Chatla Haor. These can be classified as follows: five free-floating, four rooted-floating, two submerged and 12 emergent macrophytes. Six AM can be found throughout the year. These are: Azolla pinnata, Eichhornia crassipes, Salvinia cucullata, Trapa bispinosa, Justicia repens, and Cynodon dactylon.

Justicia repens flowers during March-May, while, Nymphaea nouchali blooms during June-August followed by Nymphoides cristata and Nymphoides indica, which exhibit a profuse flowering during September-October. Ipomoea aquatica shows growth of population during July-August. Hydrilla verticillata and Vallisneria spiralis among the submerged varieties as well as Alternanthera sessilis, Cyperus platystylis, Echinochloa stagnina, Eleocharis acutangula, Enhydra fluctuans, Scirpus sp., and Sagittaria trifolia among the emergent varieties succeed at a lesser water level during the dry season. The floating varieties, namely, A. pinnata, E. crassipes, and S. cucullata are found all the year, being associated with each other. Further, $H$. verticillata and $V$. spiralis among the submerged varieties are found to be associated (Kar, 2007a).

Puneer Haor. It is situated around $38 \mathrm{~km}$ away from south of Silchar City, near the village of Dhalai, along the Assam-Mizoram border. This Haor has a water spread area of around 2.5 ha at FSL and around 1.3 ha at DSL. The maximum L, B, and D of Puneer Haor at FSL have been found to be $1.5 \mathrm{~km}, 0.9 \mathrm{~km}$ and $2.5 \mathrm{~m}$, respectively, while its average depth is $0.4 \mathrm{~m}$. The Puneer Khal, flowing along the eastern shoreline of the Haor, originates from Panchhara Hill ranges and its water spills over into the Haor at FSL. A drain from the adjoining Bhubandhar TE flows along the western shoreline of the Haor and water containing TE pollutants is believed to also spill over into the Haor at FSL (Kar, 2007a, b).

Baskandi Anua (river-formed wetland). This oxbow wetland is situated between $24^{\circ}$ $10^{\prime} \mathrm{N}$ and $93^{\circ} 15^{\prime} \mathrm{E}$ in the Lakhipur sub-division of Cachar District. It has been formed due to changes in course of the Barak River.

The Anua is situated near the Manipur range of hills. The catchment soil is found to be mainly sandy loam. Rain is the main source of water for the Anua. The wetland also receives water from the surrounding catchment having human habitation. The catchment vegetation is represented in this case by herbs, shrubs, and trees, including a lot of bamboos.

The L, B, and A of Baskandi Anua have been found to be $2.230 \mathrm{~km}, 205 \mathrm{~m}$ and 39.2 ha at FSL, and $2.090 \mathrm{~km}, 190 \mathrm{~m}$ and 36.7 ha at DSL, respectively. The wetland basin tends to be deeper towards the southern side as compared to the northern. The Anua exhibits variable water level ranging from $0.25 \mathrm{~m}$ to $5.85 \mathrm{~m}$ at FSL (June-September) and from $0.14 \mathrm{~m}$ to 4.12 $\mathrm{m}$ at DSL (November-April) (Dhar, 2004; Kar, 2007a). 
An account of the AM of Baskandi Auua. A total of 16 species of AM have been recorded in the Baskandi Anua and they belong to: six free-floating macrophytes (Azolla pinnata, Eichhornia crassipes, Salvinia cucullata, Lemna pausicostata, Pistia stratiotes, and Wolfia sp.); two rooted submerged macrophytes (Hydrilla verticillata and Vallisneria spiralis); six rooted with floating leaves (Nymphaea nouchali, Nymphoides indica, N. cristata, Trapa bispinosa, Euryale ferox, and Nelumbo nucifera); and two rooted emergent macrophytes (Justicia repens and Muradania nudiflora). Of these, six AM species have been found to occur throughout the year. These are Azolla pinnata, Eichhornia crassipes, Salvinia cucullata, Trapa bispinosa, and Justicia repens (Dhar et al., 2004).

Studies have revealed that wet biomass of AM range from 4.4 to $11.4 \mathrm{~kg} / \mathrm{m}^{2}$. Wet biomass is observed to be higher during monsoon and post-monsoon, reaching trough value during winter and a concomitant increasing trend during summer. Significant positive correlation of AM biomass with water temperature $(r=0.1820)$ has been recorded during the study period.

Satkarakandi Anua. This oxbow wetland is an abandoned segment of the Barak River situated at a distance of around $32 \mathrm{~km}$ from Silchar City. It lies within the jurisdiction of Katigora Revenue Circle in Cachar District of Assam. It has an L, B, and A of around $1.7 \mathrm{~km}, 0.7 \mathrm{~km}$, and $53 \mathrm{ha}$, respectively. The catchment soil is mostly loamy. At present, it seems to have a connection with the Banaimulla River (Kar, 2007a).

Sibnarayanpur Anua. This oxbow wetland is an abandoned segment of the Barak River situated at a distance of around $32 \mathrm{~km}$ from Silchar City. It lies within the jurisdiction of Katigora Revenue Circle in Cachar District of Assam. It has an L, B, and A of around $1.7 \mathrm{~km}$, $0.7 \mathrm{~km}$, and $53 \mathrm{ha}$, respectively. The catchment soil is mostly loamy. At present, it seems to have a connection with the Banaimulla River (Kar D., 2007a).

Notwithstanding the above, a comparative picture of the physic-chemical characteristics of the various studied wetlands in the region has been depicted in figure 5 (a, b, c, d).

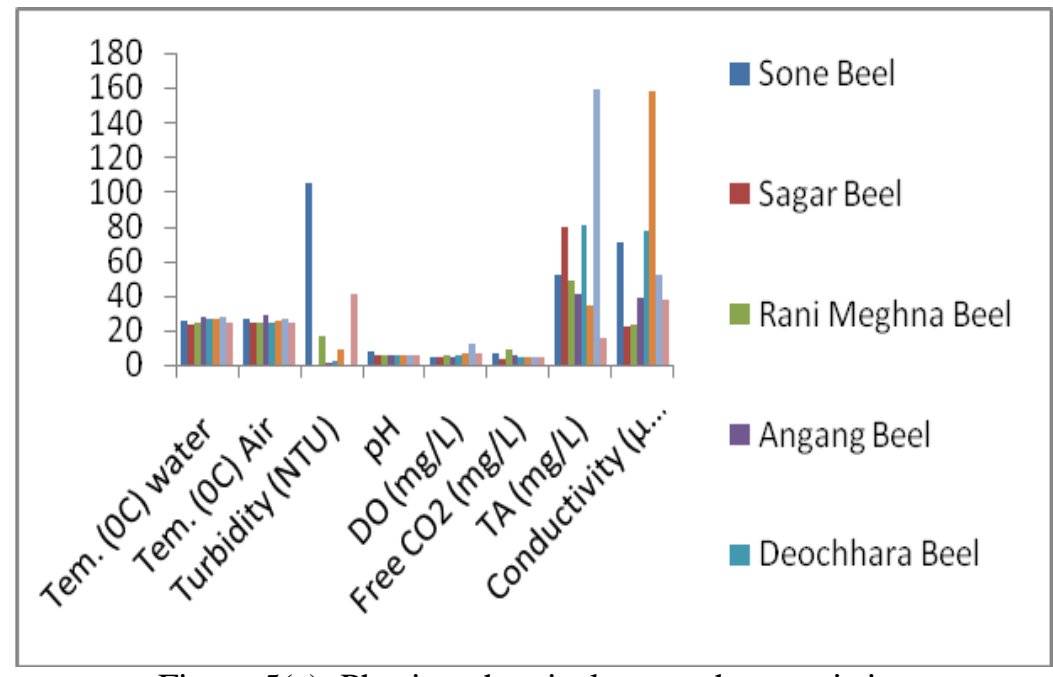

Figure 5(a): Physico-chemical water characteristics of the different studied wetlands in Assam, India. 


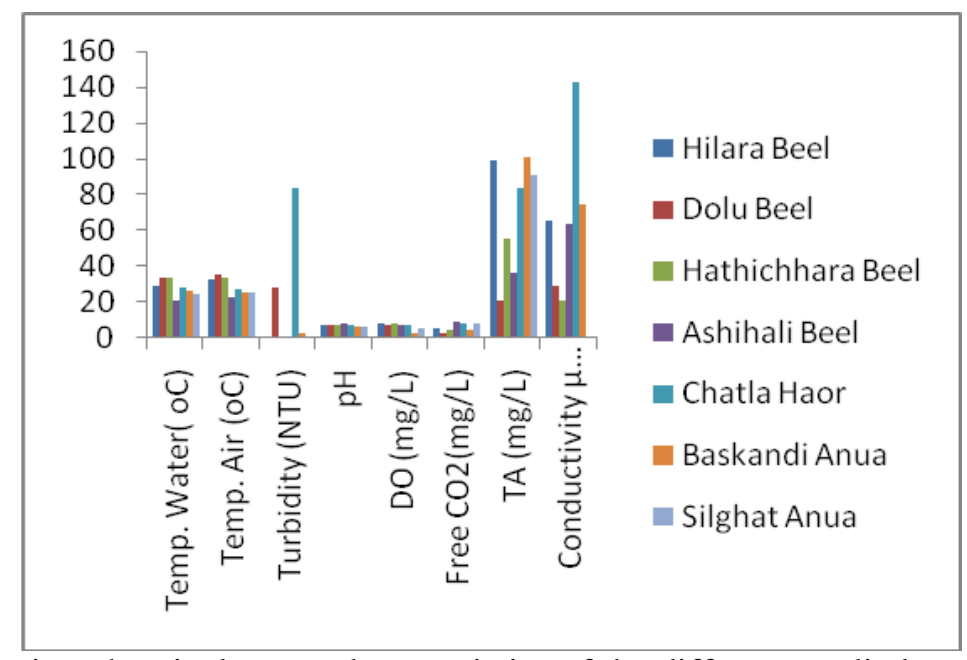

Figure 5(b): Physico-chemical water characteristics of the different studied wetlands in Assam.

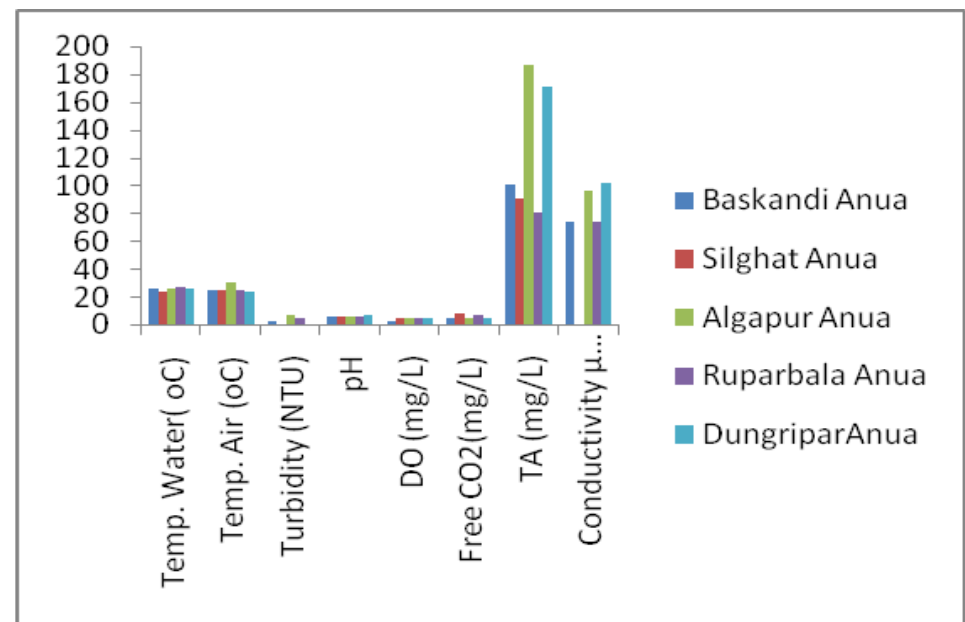

Figure 5(c): Physico-chemical water characteristics of the different studied wetlands in Assam.

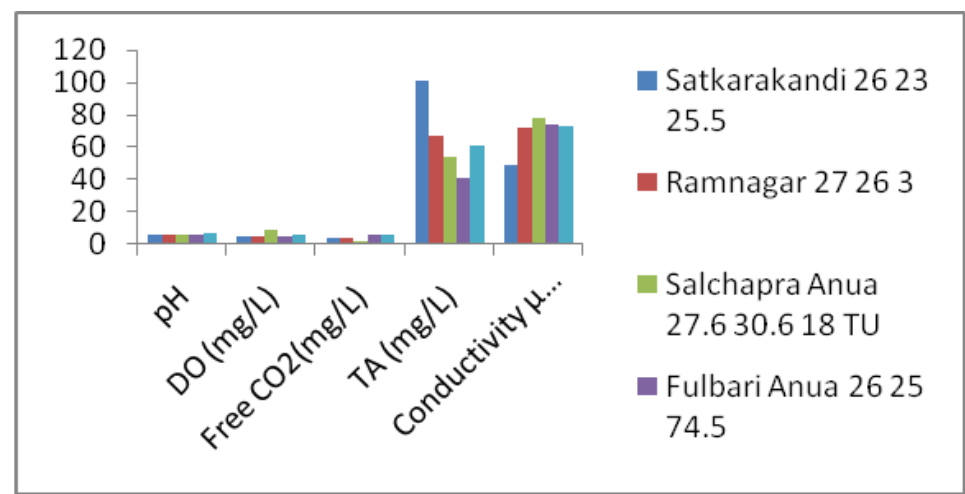

Figure 5(d): Physico-chemical water characteristics of the different studied wetlands in Assam. 


\section{Ichthyogeography and ichthyodiversity of the wetlands of Assam}

Fish constitute almost half of the total number of vertebrates in the world (Nelson, 1994). They live in almost all conceivable aquatic habitats. Around 21,723 living species of fish have been recorded out of 39,900 species of vertebrates (Nelson, 1994; Jayaram, 1999). Of these, 8,411 are freshwater species and 11,650 are marine. India has one of the mega biodiversity countries in the world and occupies 9th position in terms of freshwater biodiversity (Mittermeier and Mittermeier, 1997). In India, there are around 2,500 species of fish, of which, around 930 live in freshwater (FW) and around 1,570 are marine (Jayaram, 2010; Kar, 2003a). The rich diversity of this region could be assigned to certain reasons, notably, the geomorphology and the tectonics of this zone (Kar, 2005a, b, c). The hills and the undulating valleys of this area gives rise to large number of torrential hill streams, which lead to big rivers; and, finally, become part of the Ganga-Brahmaputra-Barak-Chindwin-Kolodyne-Gomati-Meghna system (Kar, 2000, 2007, 2013).

There is a bewildering diversity of fish in the lentic systems of this region. An account of the ichthyodiversity of the principal lentic bodies of this region is depicted in table 1 . The abundance of fish in different wetlands of Assam is portrayed in figure 6.

\section{An account of the ichthyospecies}

Zoogeographically, the freshwater fish (FW) have been classified differently by different scientists. Although the classification made by Myers (1949) has been proved to be probably the most useful and widely accepted one, the fish of marine origin have been further classified as peripheral FW forms by Nichols (1928) and Darlington (1957). Incidentally, the ichthyofauna of this region, by and large, have been found to belong to the following categories (Kar, 1990, 2007a, b):

\section{(A) Primary FW Fish}

Genera-wise break-up of the species under this group include, among others: Notopterus, Chitala, Labeo, Cirrhinus, Catla, Cyprinus, Puntius, Rasbora, Cabdio, (Aspidoparia) Morar, Amblypharyngodon, Barilius, Devario, Esomus, Salmophasia, Botia, Lepidocephalichthys, Noemacheilus, Somileptus, Rita, Mystus, Wallago, Ompok, Ailia, Eutropichthys, Clupisoma, Silonia, Pangasius, Gagata, Glyptothorax, Clarias, Heteropneustes, Chaca, Badis, Nandus, Anabas, Trichogaster, Mastacembelus, Macrognathus, and Tetraodon (Kar, 1990; 2003a, b, 2007a).

\section{(B) Peripheral FW Fish}

Genera-wise break up under this group include, among others: Gudusia, Hilsa (Tenualosa), Pisodonophis, Chanda, Xenentodon, Aplocheilus, Amphipnous, Sicamugil, Rhinomugil, and Glossogobius (Dey and Kar, 1990).

In addition to the above, on the basis of Indian and extra-Indian fish distribution (Motwani et. al., 1962), the following ichthyospecies of this region could significantly be incorporated under the following two groups:

(a) Widely distributed species

Genera-wise break up under this group include: Esomus, Puntius, Rasbora, Ompok, Wallago, Clarias, Xenentodon, Channa, Glossogobius, Anabas, Macrognathus, and Mastacembelus. These ichthyospecies, in addition to this region, also occur in India, Pakistan, Bangladesh, Sri Lanka, and Malaya (Kar and Dey, 2000a). 
(b) Species of Northern India

Species under this group include, among others: Bengana elanga, Botia dario, Lepidocephalichthys guntea, Glyptothorax telchitta, Parambassis baculis, Rhinomugil corsula, Sicamugil cascasia, and Tetraodon cutcutia (Kar and Dey, 2000a, b; 1993; Kar, 1990, 2007a, 2013a).

In addition to the foregoing analyses, ecomorphologically (Dey, 1973), the fish of this region could further be categorized into four distinct groups, which are as follows:

(a) True hill-stream or rheophilic forms

Fish with strong body musculature and adapted to torrential habitats, e.g., Garra, Psilorhynchus, Balitora, and Glyptothorax (Dey, 1973).

(b) Semi-torrential forms

Fish with less body modifications as compared to rheophilic forms, e.g., Botia, Lepidocephalichthys, Nemacheilus, Schistura, Somileptus, and Gagata.

(c) Migratory forms

Well-built fish having the power of overcoming adverse ecological conditions, such as: Hilsa (Tenualosa), Barilius, Channa, and Badis (Kar, 2002).

(d) Plainwater forms

Fish having minimum body modifications and insignificant migratory habits: Pisodonophis, Gudusia, Notopterus, Chitala, Amblypharyngodon, Cabdio, (Aspidoparia), Catla, Cirrhinus, Cyprinus, Danio, Esomus, Labeo, Puntius, Rasbora, Salmophasia, Mystus, Sperata, Ompok, Wallago, Rita, Clupisoma, Eutropiichthys, Silonia, Pangasius, Clarias, Heteropneustes, Chaca, Xenentodon, Aplocheilus, Amphipnous, Chanda, Nandus, Sicamugil, Rhinomugil, Anabas, Trichogaster, Glossogobius, Macrognathus, Mastacembelus, and Tetraodon.

\section{Fish diversity in Sone Beel of Assam}

A total of 70 species of fish belonging to 49 genera under 24 families and 11 orders have been recorded in Sone Beel, the biggest wetland in Assam.

Of the 70 ichthyospecies of Sone Beel, 59 species under 39 genera belong to the Primary FW group, while 11 species under 10 genera belong to the category of Peripheral FW group (Nichols, 1928; Darlington, 1957). On the other hand, on the basis of Indian and extraIndian territorial distribution (Motwani et al., 1962; Kar, 1990), 28 ichthyospecies of Sone can significantly be incorporated under two groups, namely, (a) widely distributed species and (b) species of Northern India. Further, among the other species, one species, namely, Glyptothorax telchitta has been found to be a true hill stream form; while, five speices, namely, Botia dario, Lepidocephalichthys guntea, Acanthocobitis botia, Somileptus gongota, and Gagata nangra are recorded as semi-torrential forms (Dey, 1973). Totally, 39 fish species belong to the plainwater group (Kar, 1990, 2007a; Dey and Kar, 1990). Incidentally, the fishermen fishing in Sone Beel belong to four communities (Kar, 1990, 2000a, 2003c, 2007a, 2013a; Dey and Kar, 1989b).

\section{Fish diversity in Sat Beel of Assam}

Fourteen species of fish, belonging to 12 genera, six families and three orders, have been recorded in Sat Beel (Kar, 2007a). 


\section{Fish diversity in Chatla Haor of Assam}

A total number of 57 species of fish, belonging to 28 genera, 17 families and nine orders, have been recorded in Chatla Haor (Kar and Barbhuiya, 2000b; Kar, 2007a, 2013a; Kar and Dey, 2002).

Zoogeographically, the ichthyospecies of Chatla Haor consist of $79.62 \%$ of primary FW fish, while the rest (20.38\%) belong to the peripheral class (Nichols, 1928; Darlington, 1957; Kar, 1990, 2007a). Further, on the basis of Indian and extra-Indian territorial fish distributional pattern (Motwani et al., 1962), ichthyospecies of Chatla Haor contain fish, which belong to the groups called widely distributed species (notably, Puntius, Ompok, Channa, Anabas) and species of Northern India (notably, Botia dario, Lepidocephalichthys guntea, etc.). Ecomorphologically (Dey, 1973), fish species of Chatla Haor contain only the "semitorrential" forms and the "plainwater" forms (notably A. mola, C. catla, C. carpio, Puntius spp., and Mystus spp.) (Kar, 2007a).

\section{Fish Diversity in Puneer Haor of Assam}

The Puneer Haor contains altogether 24 species of fish belonging to 22 genera, 15 families and eight orders (Laskar et al., 2002).

\section{Fish diversity in the Anuas of Assam}

\section{Rupairbala Anua}

In this Anua, 24 species of fish belonging to 21 genera, 15 families and nine orders have been recorded (Kar, 2000b, 2007a; Kar et al., 2000a, b, c).

\section{Baskandi Anua}

In Baskandi Anua, 13 species of fish belonging to 10 genera, six families and four orders have been recorded (Kar, 2007a; Kar et al., 2000a, b, c; Dhar, 2004).

\section{Fulbari Anua}

In course of a pilot survey, seven species of fish, belonging to six genera, six families and six orders, have been recorded from Fulbari Anua (Kar et al., 2000a, b, c).

\section{Sibnarayanpur Anua}

A total of 22 species of fish belonging to 21 genera, 10 families and five orders have been recorded from Sibnarayanpur Anua (Kar et al., 2000a, b, c). 
Table 1: Fish diversity in southern Assam Wetlands (“+” Present, “_” Absent).

\begin{tabular}{|c|c|c|c|c|c|c|c|c|}
\hline Fish species & $\begin{array}{l}\bar{\Xi} \\
\tilde{D} \\
\tilde{D} \\
\tilde{D}\end{array}$ & 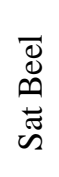 & 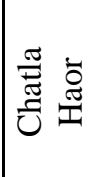 & 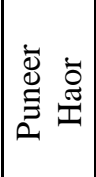 & 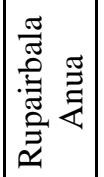 & 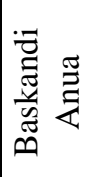 & 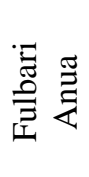 & 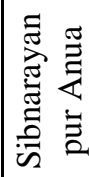 \\
\hline Pisodonophis boro (Hamilton) & + & - & - & - & - & - & - & - \\
\hline Gudusia chapra Hamilton) & + & - & + & - & + & - & + & + \\
\hline Tenualosa ilisha (Hamilton) & + & - & + & - & - & - & - & - \\
\hline Chitala chitala (Hamilton & + & - & + & - & - & - & - & - \\
\hline Notopterus notopterus (Pallas) & + & - & + & + & + & - & - & - \\
\hline Amblypharyngodon mola (Hamilton) & + & + & + & + & + & + & - & - \\
\hline Aspidoparia morar (Hamilton) & + & - & - & - & - & - & - & - \\
\hline Barilius bendelisis (Hamilton) & + & - & - & - & - & - & - & - \\
\hline Osteobrama cotio (Hamilton) & - & - & - & - & - & - & - & + \\
\hline Catla catla (Hamilton) & + & - & + & - & - & - & - & + \\
\hline Cirrhinus mrigala (Hamilton) & + & - & + & - & - & - & - & + \\
\hline Cirrhinus reba (Hamilton) & + & - & + & + & - & - & - & - \\
\hline Chela laubuca (Hamilton) & + & - & - & - & - & - & - & + \\
\hline Cyprinus carpio (Linnaeus) & + & + & + & - & - & - & - & - \\
\hline Ctenopharyngodon idellus (Valenciennes) & - & - & + & - & - & - & - & - \\
\hline Hypophthalmichthys molitrix (Valenciennes) & - & - & + & - & - & - & - & - \\
\hline Devario devario (Hamilton) & + & - & + & - & - & - & - & - \\
\hline Esomus danricus (Hamilton) & + & - & + & - & - & - & - & + \\
\hline Labeo bata (Hamilton) & + & - & - & - & - & - & - & - \\
\hline Labeo calbasu (Hamilton) & + & + & + & + & - & - & - & - \\
\hline Labeo gonius (Hamilton) & + & - & + & - & + & - & - & + \\
\hline Labeo nandina (Hamilton) & + & - & - & - & - & - & - & - \\
\hline Labeo rohita (Hamilton) & + & - & + & - & - & - & - & - \\
\hline
\end{tabular}


Table 1 (continued): Fish diversity in southern Assam Wetlands (“+” Present, “-” Absent).

\begin{tabular}{|c|c|c|c|c|c|c|c|c|}
\hline Fish species & $\begin{array}{l}\bar{\Phi} \\
\tilde{D} \\
\mathscr{\Xi} \\
\tilde{D}\end{array}$ & 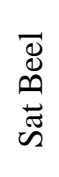 & 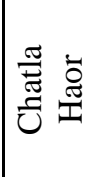 & 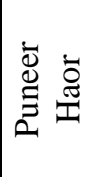 & 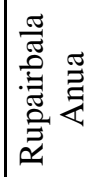 & 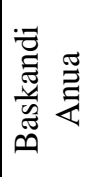 & 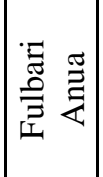 & 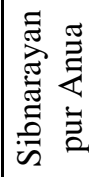 \\
\hline Pisodonophis boro (Hamilton) & + & - & - & - & - & - & - & - \\
\hline Gudusia chapra Hamilton) & + & - & + & - & + & - & + & + \\
\hline Puntius chola (Hamilton) & + & + & + & - & + & - & + & + \\
\hline Puntius conchonius (Hamilton) & + & - & + & + & + & + & - & + \\
\hline Puntius saranasarana (Hamilton) & + & - & + & - & - & - & - & - \\
\hline Puntius ticto (Hamilton) & + & + & + & + & + & + & + & + \\
\hline Rasbora daniconius (Hamilton) & + & - & + & - & - & + & - & - \\
\hline Bengana elanga (Hamilton) & + & - & - & - & - & - & - & - \\
\hline Salmophasia bacaila (Hamilton) & + & - & + & + & - & + & - & + \\
\hline Securicula gora (Hamilton) & - & - & - & + & + & - & - & + \\
\hline Botia dario (Hamilton) & + & - & + & - & + & - & - & - \\
\hline Lepidocephalichthys guntea (Hamilton) & + & + & + & - & + & - & - & - \\
\hline Acanthocobitis botia (Hamilton) & + & - & + & - & - & - & - & - \\
\hline Somileptus gongota (Hamilton) & + & - & - & - & - & - & - & - \\
\hline Mystus bleekeri (Day) & - & + & - & + & - & - & + & - \\
\hline Mystus cavacious (Hamilton) & + & - & + & - & + & - & + & - \\
\hline Mystus corsula (Hamilton) & + & - & + & - & - & - & - & - \\
\hline Pisodonophis boro (Hamilton) & + & - & - & - & - & - & - & - \\
\hline Gudusia chapra (Hamilton) & + & - & + & - & + & - & + & + \\
\hline Tenualosa ilisha (Hamilton) & + & - & + & - & - & - & - & - \\
\hline Chitala chitala (Hamilton) & + & - & + & - & - & - & - & - \\
\hline Notopterus notopterus (Pallas) & + & - & + & + & + & - & - & - \\
\hline Amblypharyngodon mola (Hamilton) & + & + & + & + & + & + & - & - \\
\hline Aspidoparia morar (Hamilton) & + & - & - & - & - & - & - & - \\
\hline Barilius bendelisis (Hamilton) & + & - & - & - & - & - & - & - \\
\hline Osteobrama cotio (Hamilton) & - & - & - & - & - & - & - & + \\
\hline Catla catla (Hamilton) & + & - & + & - & - & - & - & + \\
\hline Cirrhinus mrigala (Hamilton) & + & - & + & - & - & - & - & + \\
\hline Cirrhinus reba (Hamilton) & + & - & + & - & - & - & - & - \\
\hline Chela laubuca (Ham) & + & - & + & - & - & - & - & - \\
\hline Cyprinus carpio (Linnaeus) & + & + & + & - & - & - & - & - \\
\hline Ctenopharyngodon idellus (Valenciennes) & - & - & + & - & - & - & - & - \\
\hline Hypophthalmichthys molitrix (Valenciennes) & - & - & + & - & - & - & - & - \\
\hline Devario devario (Hamilton) & + & - & + & - & - & - & - & - \\
\hline Esomus danricus (Hamilton) & + & - & + & - & - & - & - & + \\
\hline Labeo bata (Hamilton) & + & - & + & - & - & - & - & + \\
\hline Labeo calbasu (Hamilton) & + & + & + & + & - & - & - & + \\
\hline Labeo gonius (Hamilton) & + & - & + & - & + & - & - & + \\
\hline
\end{tabular}


Table 1 (continued): Fish diversity in southern Assam Wetlands (“+” Present, “_” Absent).

\begin{tabular}{|c|c|c|c|c|c|c|c|c|}
\hline Fish species & $\begin{array}{l}\bar{\Phi} \\
\infty \\
0 \\
0 \\
0 \\
0\end{array}$ & $\begin{array}{l}\bar{\Xi} \\
\infty \\
\ddot{E} \\
\infty\end{array}$ & 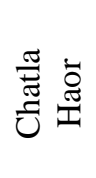 & 离 & 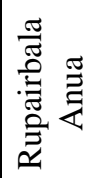 & 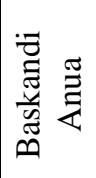 & 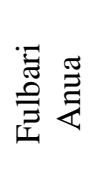 & 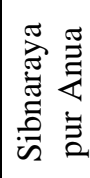 \\
\hline Pisodonophis boro (Hamilton) & + & - & - & - & - & - & - & - \\
\hline Gudusia chapra Hamilton) & + & - & + & - & + & - & + & + \\
\hline Puntius chola (Hamilton) & + & + & + & - & - & - & - & - \\
\hline Labeo nandina (Hamilton) & + & - & - & - & - & - & - & - \\
\hline Labeo rohita (Hamilton) & + & - & + & - & - & - & - & + \\
\hline Puntius chola (Hamilton) & + & + & + & - & - & - & - & - \\
\hline Puntius conchonius (Hamilton) & + & - & + & + & + & + & - & + \\
\hline Puntius saranasarana (Hamilton) & + & - & + & - & - & - & - & - \\
\hline Puntius ticto (Hamilton) & + & + & + & + & + & + & + & + \\
\hline Securicula gora (Hamilton) & - & - & - & + & + & - & - & + \\
\hline Botia dario (Hamilton) & + & - & + & - & + & - & - & - \\
\hline Lepidocephalichthys guntea (Hamilton) & + & + & + & - & + & - & - & - \\
\hline Acanthocobitis botia (Hamilton) & + & - & + & - & - & - & - & - \\
\hline Somileptus gongota (Hamilton) & + & - & - & - & - & - & - & - \\
\hline Mystus bleekeri (Day) & - & + & - & + & - & - & + & - \\
\hline Mystus cavacious (Hamilton) & + & - & + & - & + & - & + & - \\
\hline Mystus corsula (Hamilton) & + & - & + & - & - & - & - & - \\
\hline Mystus tengara (Hamilton) & + & - & + & - & - & - & - & - \\
\hline Mystus vittatus (Bloch) & + & + & + & + & - & - & - & - \\
\hline Sperata seenghala (Sykes) & + & + & + & - & - & - & - & - \\
\hline Rita rita (Hamilton) & + & - & - & + & - & - & - & + \\
\hline Ompok bimaculatus (Bloch) & + & + & + & + & + & - & - & - \\
\hline Rasbora daniconius (Hamilton) & + & - & + & - & - & + & - & - \\
\hline Bengana elanga (Hamilton) & + & - & - & - & - & - & - & - \\
\hline Salmophasia bacaila (Hamilton) & + & - & + & + & - & + & - & + \\
\hline Wallago attu (Bloch and Schneider) & + & + & + & - & - & - & - & - \\
\hline Ailia coila (Hamilton) & + & - & + & - & - & - & - & - \\
\hline Clupisoma atherinoides (Hamilton) & + & - & + & - & - & - & - & - \\
\hline Clupisoma garua (Hamilton) & + & + & + & - & - & - & - & + \\
\hline Eutropiichthys vacha (Hamilton) & + & - & + & - & - & - & - & + \\
\hline Eutropiichthys murius (Hamilton) & - & - & + & - & - & - & - & - \\
\hline Silonia silondia (Hamilton) & + & - & - & - & - & - & - & - \\
\hline Pangasius pangasius (Hamilton) & + & - & - & - & - & - & - & - \\
\hline Nangra nangra (Hamilton) & + & - & - & - & - & - & - & - \\
\hline Glyptothorax telchitta (Hamilton) & + & - & - & - & - & - & - & - \\
\hline Clarias batrachus (Linnaeus) & + & - & + & + & - & - & - & + \\
\hline
\end{tabular}


Table 1 (continued): Fish diversity in southern Assam Wetlands (“+” Present, “-” Absent).

\begin{tabular}{|c|c|c|c|c|c|c|c|c|}
\hline Fish species & 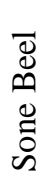 & 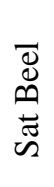 & 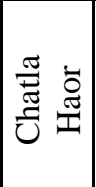 & 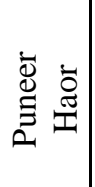 & 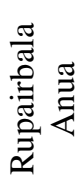 & 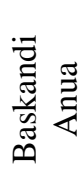 & 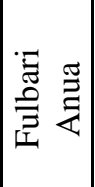 & 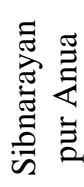 \\
\hline Heteropneustes fossilis (Bloch) & + & - & + & + & - & - & - & - \\
\hline Chaca chaca (Hamilton) & + & - & - & - & - & - & - & - \\
\hline Xenentodon cancila (Hamilton) & + & - & + & + & + & - & - & + \\
\hline Aplocheilus panchax (Hamilton) & + & - & + & + & + & - & - & - \\
\hline Channa orientalis (Schneider) & + & - & + & - & - & - & - & - \\
\hline Channa marulius (Hamilton) & + & - & - & - & - & + & - & - \\
\hline Channa punctata (Bloch) & + & + & + & + & - & + & + & - \\
\hline Channa striata (Bloch) & + & - & + & - & - & + & - & - \\
\hline Amphipnous cuchia (Hamilton) & + & - & + & - & - & - & - & + \\
\hline Parambassis baculis (Hamilton). & + & - & + & - & + & - & - & - \\
\hline Parambassis ranga (Hamilton) & - & - & + & + & + & + & + & - \\
\hline Chanda nama (Hamilton) & + & - & + & - & + & - & - & + \\
\hline Badis badis (Hamilton) & + & - & + & - & + & + & - & + \\
\hline Nandus nandus (Hamilton) & + & - & + & + & - & - & - & - \\
\hline Oreochromis mossambica (Peters) & - & - & - & + & + & - & - & - \\
\hline Rhinomugil corsula (Hamilton) & + & - & - & - & - & - & - & - \\
\hline Sicamugil cascasia (Hamilton) & + & - & - & - & - & - & - & - \\
\hline Glossogobius giuris (Hamilton) & + & - & + & - & + & + & - & - \\
\hline Anabas testudineus (Bloch) & + & - & + & + & + & - & - & - \\
\hline Trichogester fasciata (Schneider) & + & - & + & + & + & - & - & - \\
\hline Trichogester lalia (Hamilton) & - & - & + & - & + & - & - & - \\
\hline Trichogester sota (Hamilton) & - & - & - & + & - & - & - & - \\
\hline Macrognathus aral (Bloch and Schneider) & + & - & + & - & - & + & - & - \\
\hline Macrognathus pancalus (Hamilton) & + & + & + & - & + & + & + & + \\
\hline Mastacembelus armatus (Lacepede) & + & - & + & + & - & - & - & + \\
\hline Tetraodon cutcutia (Hamilton) & + & - & - & - & + & - & - & - \\
\hline
\end{tabular}




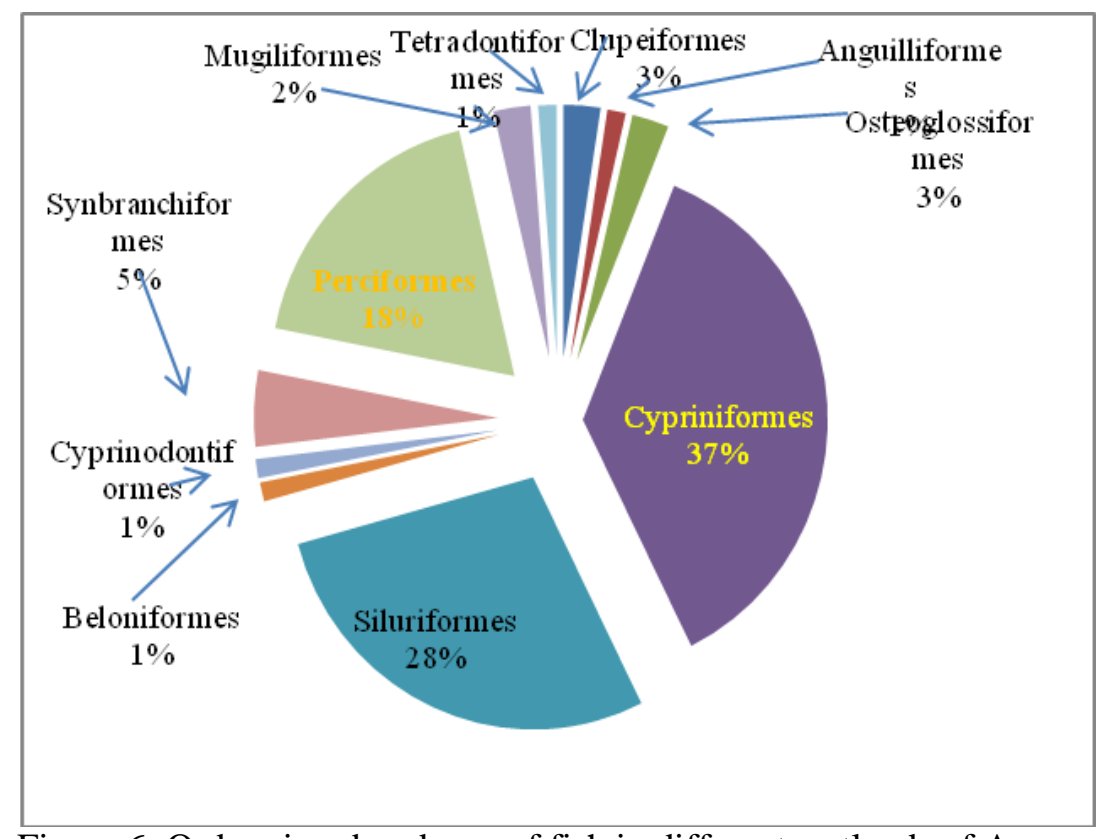

Figure 6: Orderwise abundance of fish in different wetlands of Assam.

Management and conservation of wetlands: A case study in Sone Beel in Assam

Profitable harnessing of fish resources from these natural "Beels" depend today on systematic management of these water bodies (Kar et al., 1996b; Kar, 2007a, 2013a). Sone Beel could be considered as an example.

At dead storage level (DSL), Sone Beel has eight deeper fishing centres locally called "Bundhs" (November - April: 5 ha - around 200 ha; depth: $1 \mathrm{~m}-1.75 \mathrm{~m}$ ). Now the "Bundhs" witness only "Capture Fishing".

Conversely, scientific pisciculture in these "Bundhs" could increase the fish yield (FY) and could generate employment and income.

Concomitantly, certain other measures, forming part of the management strategies, (which could also be applicable to other similar "Beels") are as follows:

1. Regulation of siltation at the upstream region of the inlet(s) coupled with construction of "check dams", wherever necessary, along with concomitant allotment of "Patta" (land ownership right) to the local inhabitants to prevent further encroachment into the Beel mainly for paddy cultivation.

2. Leasing-out of the Sone Beel to Peoples' Organisations as Sone Beel Fishermens' Co-operative Society (SBFCS) instead of individuals with complete responsibility of its management to SFFCS; as well as, imposition and realization of its proper monetary share. Government may do developmental works through the earnings.

3. SEFCS may further earn through collection of token tolls from the fishermen as well as the fish traders on the basis of fish caught and purchased, respectively.

4. The generation of employment and income through proper management would prevent avaricious exploitation of the Beel, check exodus of fishermen from the Beel to the cities; and, thus, would help conserving fishermen as fishermen. 
5. Proper steps to be taken by the Board of Management to control fish disease such as the Epizootic Ulcerative Syndrome (EUS) in order to prevent large scale mortality of fish.

6. Similar management strategies could be thought in other lentic and lotic systems.

\section{Habitat mapping by remote sensing}

Remote Sensing (RS) tools have an important role in applications relating to wetland monitoring and mapping. In optical RS, the visible and infra-red part of the electromagnetic spectrum is used to characterize objects. However, during monsoon season, the suitable atmospheric windows for acquisition of optical data are limited to cloud-free periods. This is a major lacuna for wetland applications because wetlands are highly seasonal and dynamic systems compared to terrestrial ecosystems. The radar imaging systems are said to overcome many of these limitations by providing increased canopy penetrations and day and night acquisitions nearly independent of weather conditions (Ramsey, 1995; Ramsey and Laine, 1997). Therefore, it is imperative to use radar data for a better understanding of the dynamics of wetland ecosystems as well as their assessment, monitoring and management. There are also several advantages of using microwave data. Microwave sensors have a unique sensitivity to the moisture content of the earth material. They are also highly sensitive to textural properties of vegetative cover. Therefore, they can be used to discriminate between grasses, aquatic vegetation, forest, and crop cover. In this way, the surrounding people can use them to identify the encroachment inside a national park for agricultural activities.

Identification of different habitats is also a main activity for wetland monitoring and management. Studies have indicated that Synthetic Apeliure Radar data are far superior to optical satellite data in the delineation of open water habitat and aquatic vegetation. Although radar remote sensing could play an important role in wetlands, so far, very little amount of work has been done and there is huge potential to explore and exploit the different capabilities of radar data for wetland research. High Incidence Angle Radar data have been used to delineate the open water habitat with aquatic vegetation critical to waterfowl in wetlands. The study of Keoladeo Ghana National Park in Bharatpur has shown that radar data are three to four times better in delineating the extent of open water, aquatic vegetation categories and also localities of high soil moisture content (Srivastava et al., 2001). Such information could be of great significance in formulating Habitat Suitability Index (BS) models for a variety of species.

\section{Wetland habitat mapping exemplified}

An attempt has been made to map few wetlands in Assam in GIS platform (Figs. 7-34).

Using IRS-IC, LISS-III and IV data, mapping of some of the wetlands in Assam have been done preliminarily using GIS software. The study reveals that almost all the wetlands of Assam are affected by siltation. They are shallow and some of them are not rich in aquatic macrophytes. Turbidity is generally high during rainy season. Land use pattern mainly involves fishing and sometimes cultivation of paddy mainly during the spring season.

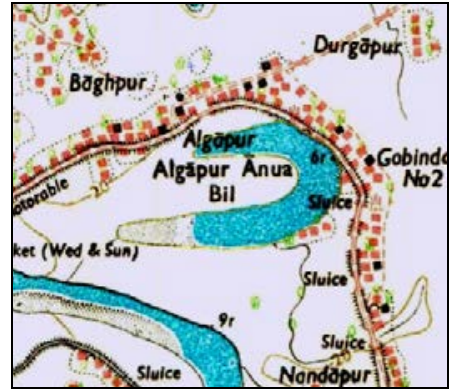

Figure 7: Algapur Anua.

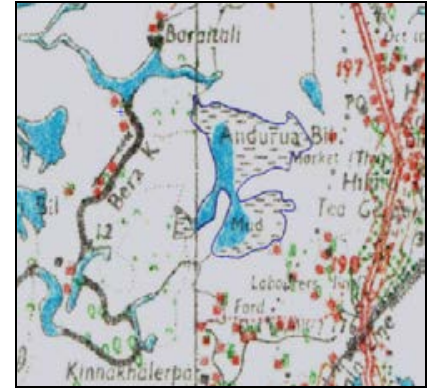

Figure 8: Andhurua Beel.

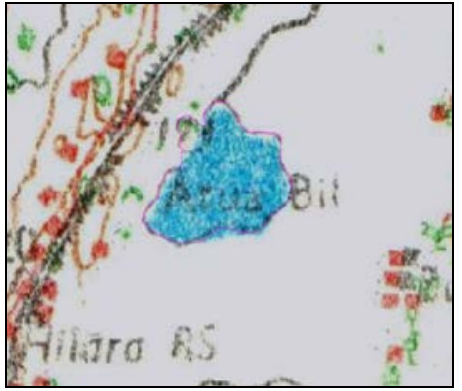

Figure 9: Atoa Beel. 


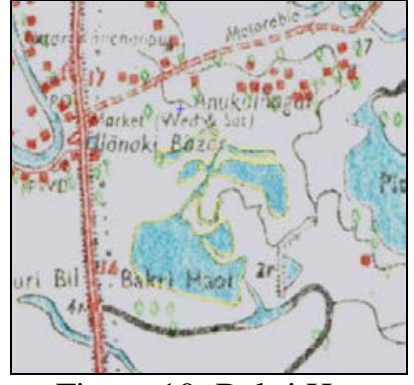

Figure 10: Bakri Haor.

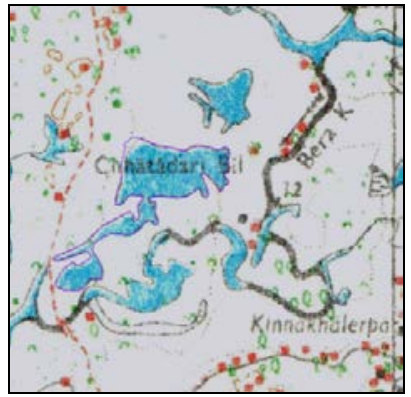

Figure 13: Chatradharia Beel.

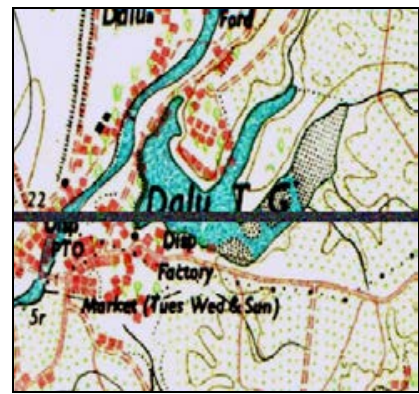

Figure 16: Dolu Lake.

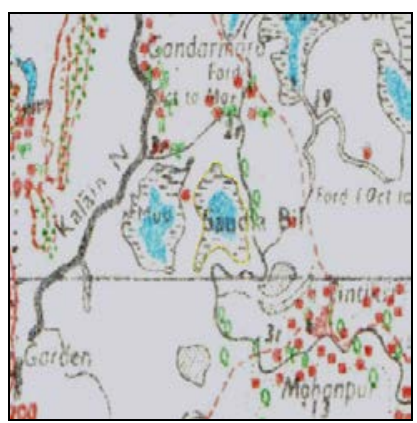

Figure 19: Suskacharua Beel.

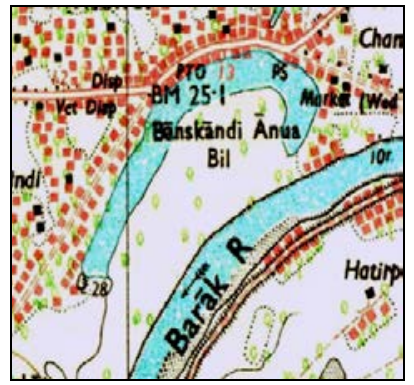

Figure 11: Baskandi Anua.

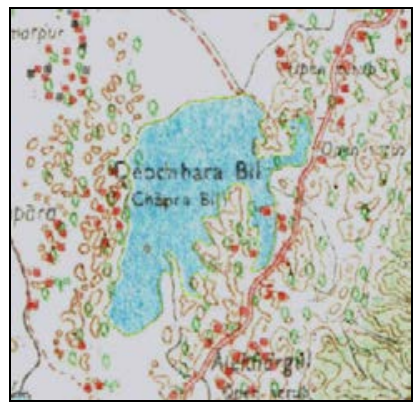

Figure 14. Deocherra Beel.

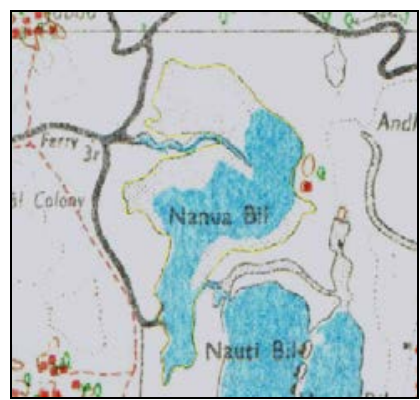

Figure 17: Jabda Beel.

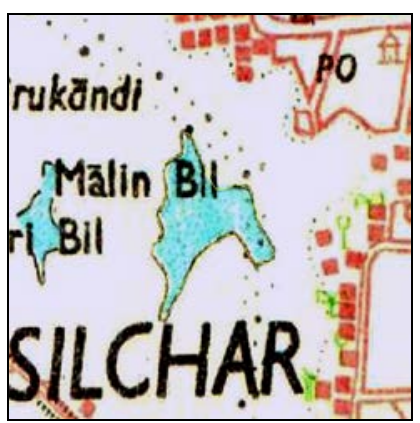

Figure 20: Malini Beel.

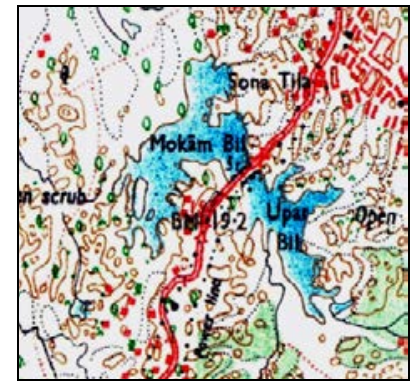

Figure 12: Chatla Haor.

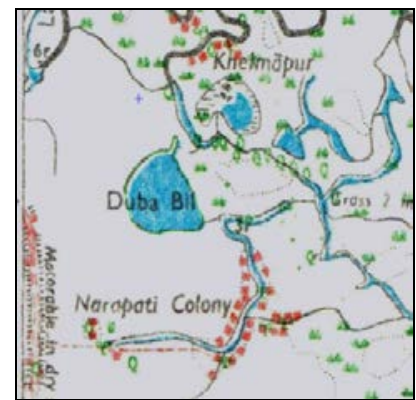

Figure 15: Dholi Beel.

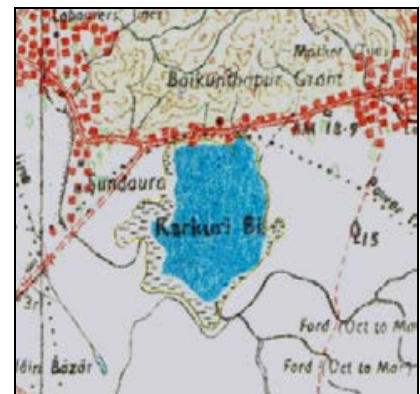

Figure 18: Korkori Beel.

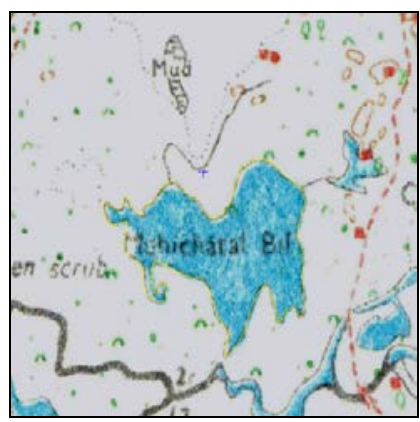

Figure 21: Mahisatal Beel. 


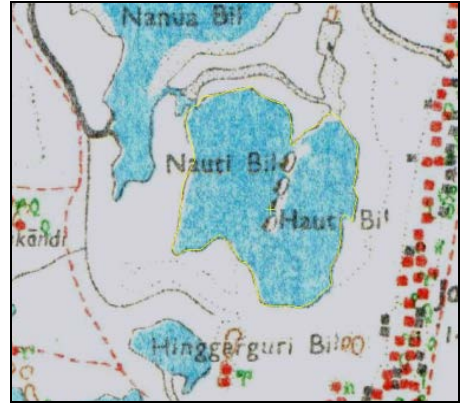

Figure 22: Outi-bouti Beel.

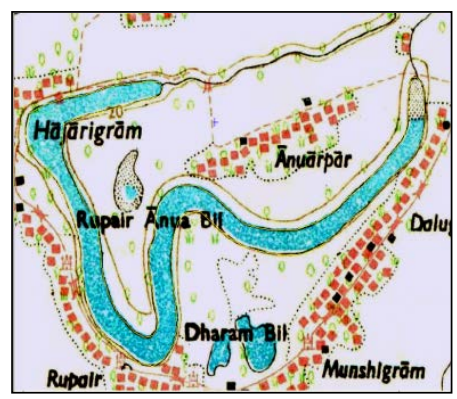

Figure 25: Rupairbala Anua.

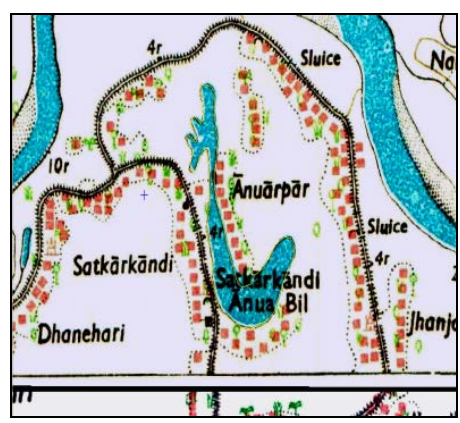

Figure 28: Satkarakandi Anua.

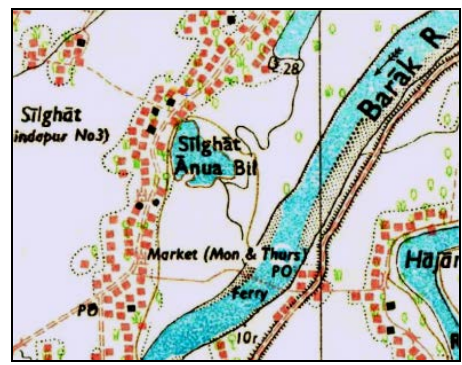

Figure 31: Silghat anua.

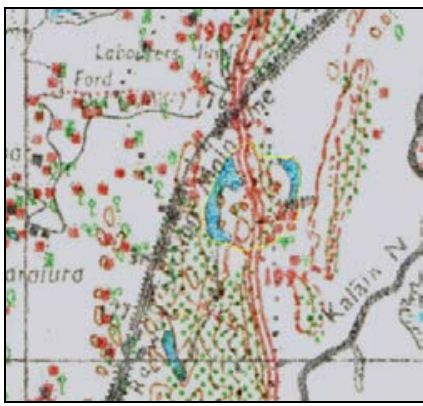

Figure 23: Petoa Beel.

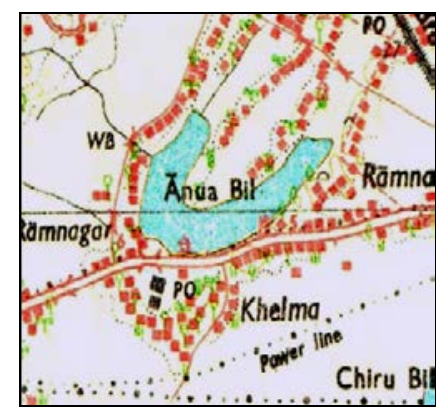

Figure 26: Ramnagar Anua.

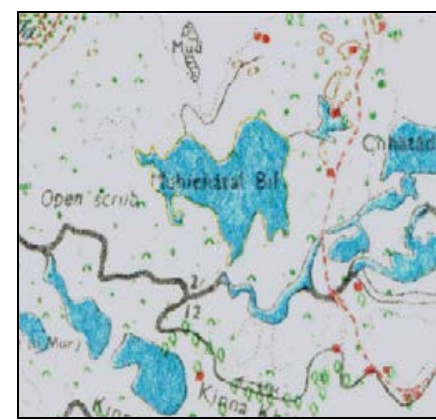

Figure 29: Mohisatal Beel.

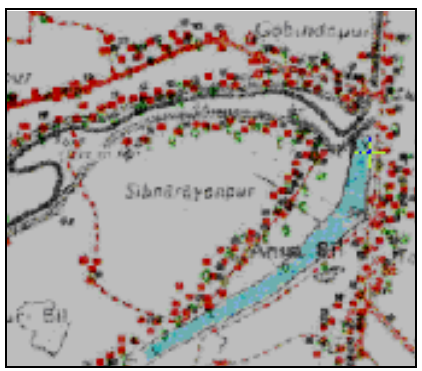

Figure 32: Shivnarayanpur Anua.

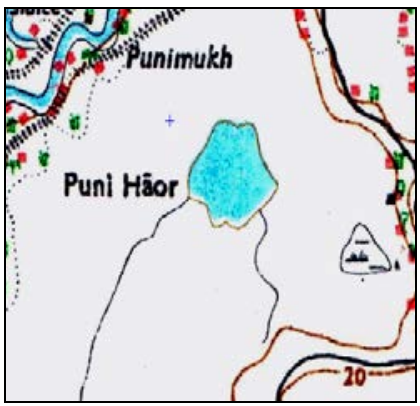

Figure 24: Punir Haor.

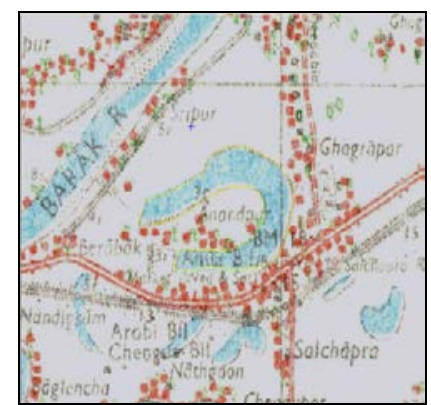

Figure 27: Salchapra Anua.

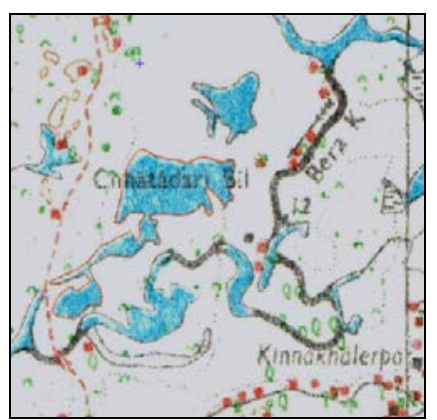

Figure 30: Chatradharia Beel.

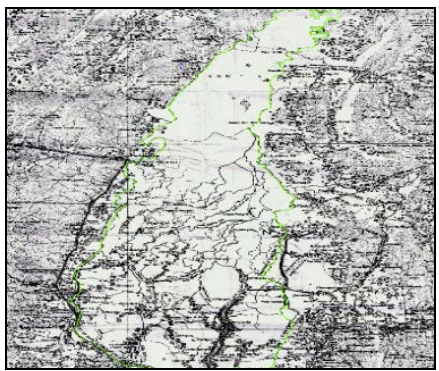

Figure 33: Sone Beel. 


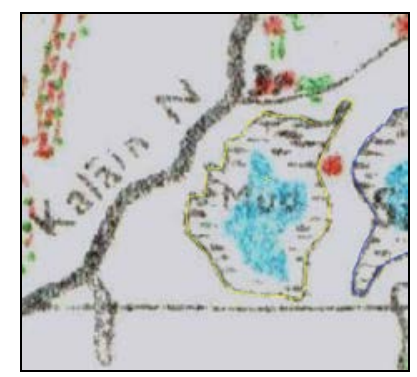

Figure 34: Kuria Beel.

\section{Epizootic Ulcerative Syndrome (EUS fish disease)}

The dreadful and virulent Epizootic Ulcerative Syndrome (EUS) has been sweeping the freshwater fish (FW) in an epidemic dimension, unhindered, unimpeded and unabated, almost semi-globally today. This disease has caused large-scale mortality among fish since 1988, rendering many of them endangered. It also leads to fear psychosis among the fisheating people, causing untold misery to the fishermen and fish farmers, as well as devastation to the economy of the nation. The epizootic ulcerative syndrome has revealed fluctuations in its intensity in relation to species affected. Our studies, involving aspects, such as: limnology, chemistry, physics, bacteriology, mycology, and virology, including tissue culture and electron microscopy, have revealed interesting findings including isolation of a virus. There is urgent need for managing this unimpeded fish disease (Plates 1, 2, 3) (Kar, 2015).

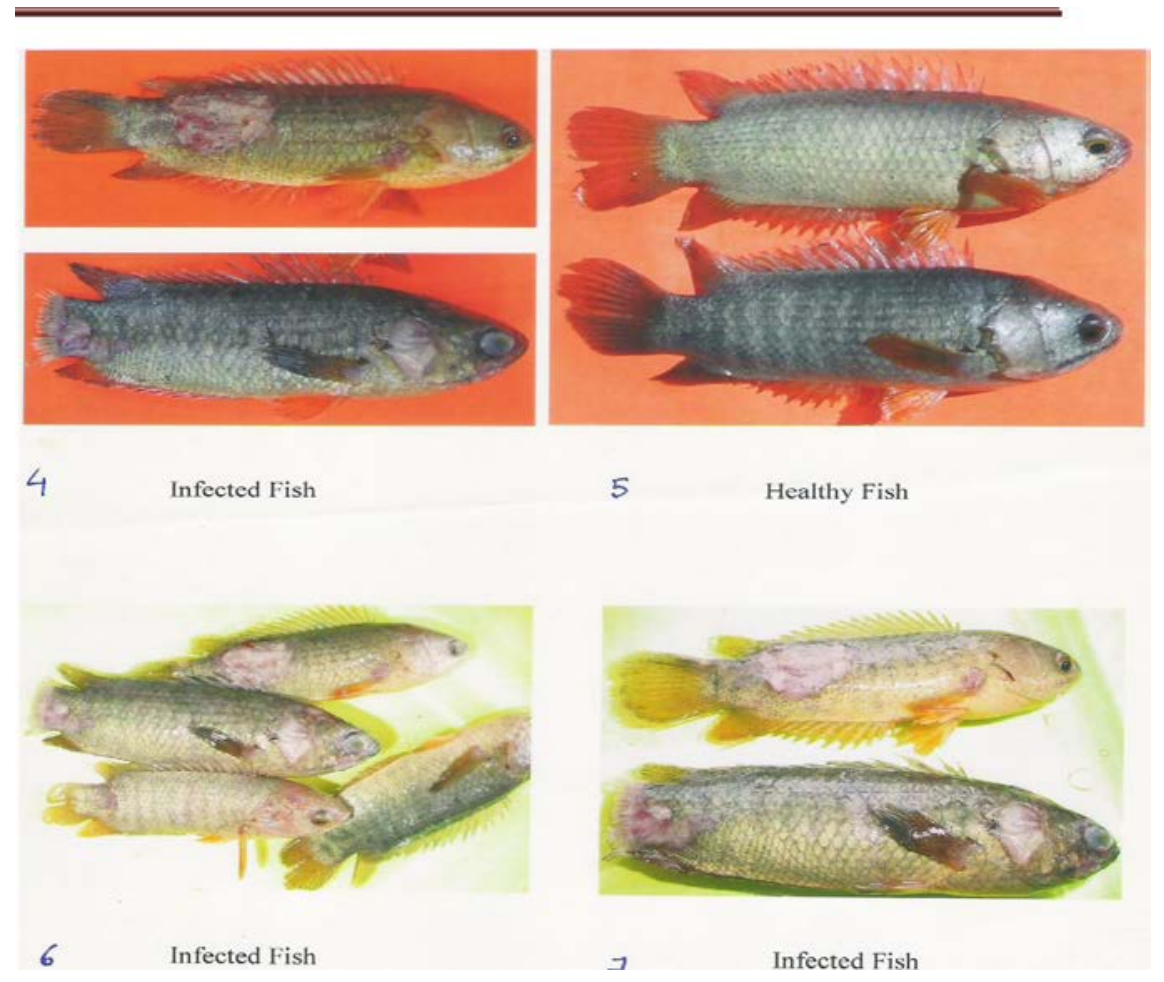

Plate 1: Some of the fish species affected by the epizootic ulcerative syndrome (EUS) fish disease. 

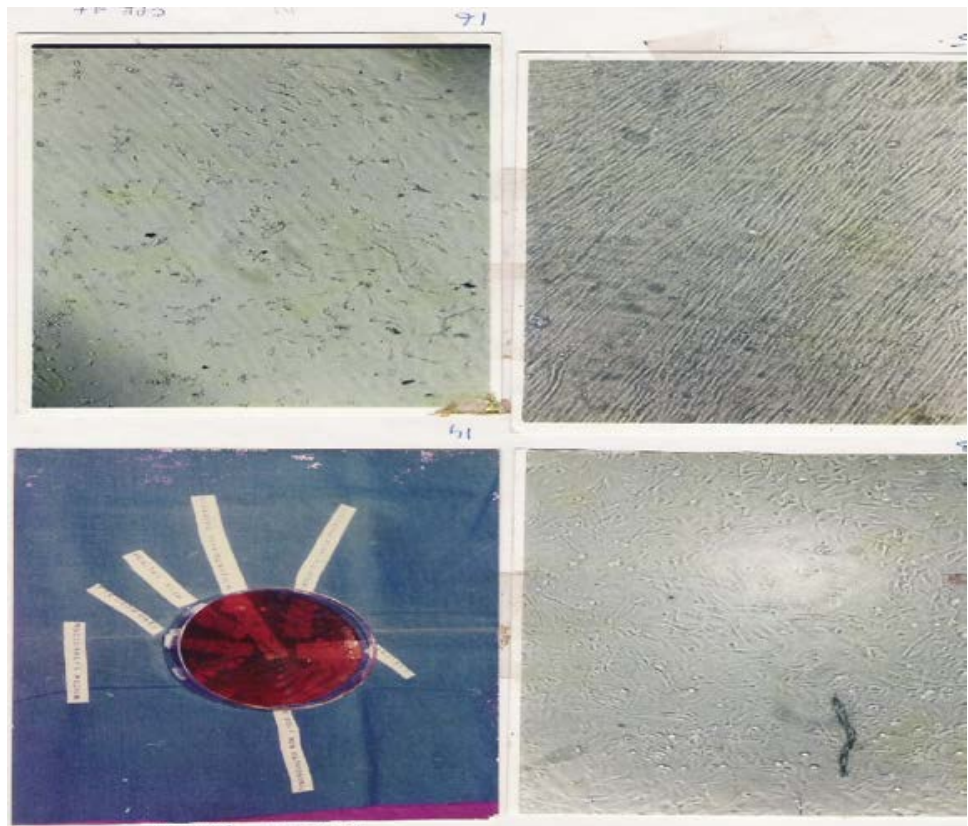

Plate 2: Microbiological and tissue cultural isolation of EUS fish bacteria and virus.

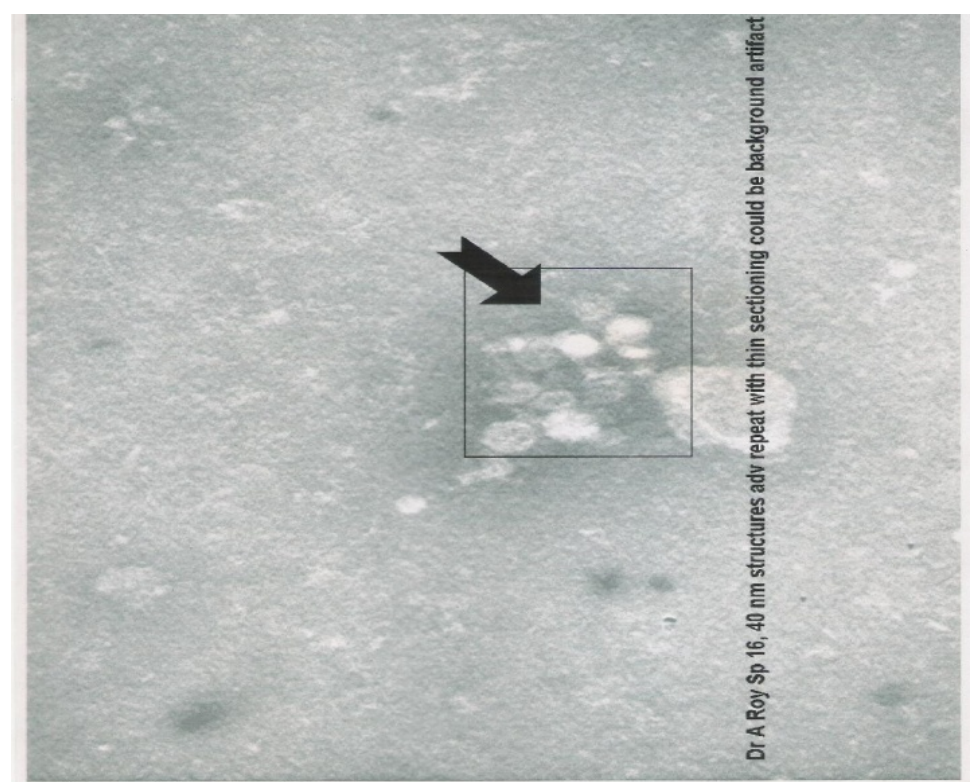

Plate 3: An electron micrograph of Picobirna Virus considered being the primary aetiology of EUS fish disease.

In addition to the above, present status of the wetlands in this region with regard to their potentialities and problems have been summarized in table 2 . The wetlands in this region could function very well with regard to pisciculture and flood management in this severely flood-prone area. They could also serve significantly in the rehabilitation of the innumerable immigrated fishermen. 
The potentialities of Beels, Haors and Anuas are reflected in the many aspects presented here: vast waterspread area, presence of continuous inlets and outlets, maximum depth sometimes up to six metres, occurrence of high fish diversity to the extent of 70 species in a single Beel (Sone Beel), presence of migratory Hilsa in some of the Beels, etc. Likewise, some of the Haors have rich diversity of phyto- and zooplankton and occurrence of juveniles of IMCs and Hilsa; thus, indicating such wetlands serving as possible natural breeding grounds of IMCs and Hilsa. The Anuas, being detached from original course of the rivers, could serve as ideal sites for culture fishery.

Notwithstanding the above, significant problems faced by these wetlands are mostly man-induced, e.g., diversification of the course of the inlets and blocking of the outlets, which results in siltation of the Beels and the channels due to less expulsion of silt from the Beel and leads to diminution of depth and water-spread area rendering loss of breeding ground for the large growing fish (LGF); exposure of the land, their subsequent encroachments and paddy cultivation often using chemical fertilizers and pesticides. Day-in and day-out fishing operations by thousands of unrehabilitated fishermen using 26 different types of fishing gears (some of which are fine-meshed) and methods (Kar, 2007a, 2013a) is a problem of concern. Acute weed problems in some of the "Anuas" are another problem of serious concern.

Some of the important suggestions include removal/modification of man-made blockades in order to revive the migration of fish, to help boost fish trade through navigation and to enable some amount of natural desiltation. Furthermore, proposed measures include: some amount of man-made desiltation could revive the breeding ground of the LGF, discourage paddy cultivation due to re-submergence of the exposed wetland beds; rehabilitation of the innumerable immigrated fishermen, minimum education and monitoring of the wetland users by the NGOs for less input towards eutrophication; culture of IMCs in the deep fishing centres at the DSL to boost local earnings; and, initiation/re-vamping of the Fishermen Co-operative Societies. These measures could contribute to maintainig the health of the Wetlands and Wetland-users and in the emancipation of the poor fishermen. 
Table 2: Potentialities and problems of the wetlands in Assam.

\begin{tabular}{|c|c|c|}
\hline Wetlands & Potentialities & Problems \\
\hline Sone Beel & $\begin{array}{l}\text { Biggest wetland in } \\
\text { Assam, continuous inlet, } \\
\text { outlet, big size IMCs, } \\
\text { naturally growing Hilsa, } \\
\text { ideal site for } \\
\text { rehabilitation of } \\
\text { displaced fishermen } \\
\text { (Plate 4) }\end{array}$ & $\begin{array}{l}\text { Inlet diversifications, } \\
\text { outlet diversifications, } \\
\text { outlet blockade, siltation, } \\
\text { mahajal operation, paddy } \\
\text { cultivation, big size } \\
\text { carnivorous fish, and } \\
\text { exotic carps, day-in, day- } \\
\text { out fishing operations, } \\
\text { fish disease (EUS) }\end{array}$ \\
\hline Sat Beel & $\begin{array}{l}\text { Near the rivers Barak } \\
\text { and Madhura, ideal site } \\
\text { for culture fishery }\end{array}$ & Siltation, weeds \\
\hline Malini Beel & $\begin{array}{l}\text { Near the Barak River, } \\
\text { ideal site for culture } \\
\text { fishery and tourism }\end{array}$ & Siltation, urbanization \\
\hline Tapang Beel & $\begin{array}{l}\text { Big natural Beel, good } \\
\text { site for capture fishing }\end{array}$ & $\begin{array}{l}\text { Siltation, encroachment of } \\
\text { the Beel }\end{array}$ \\
\hline Srikona Beel & $\begin{array}{l}\text { Near the Barak River, } \\
\text { ideal site for culture } \\
\text { fishery }\end{array}$ & Weeds \\
\hline Dubria Beel & $\begin{array}{l}\text { Ideal site for culture } \\
\text { fishery }\end{array}$ & Siltation \\
\hline Hatichhara Beel & $\begin{array}{l}\text { Big size, ideal site for } \\
\text { fish stocking }\end{array}$ & $\begin{array}{l}\text { Turbidity, tea garden } \\
\text { effluents }\end{array}$ \\
\hline Doloo Beel & $\begin{array}{l}\text { Big size, ideal site for } \\
\text { fish stocking }\end{array}$ & Tea garden effluents \\
\hline Hotoir Beel & $\begin{array}{l}\text { Potential site for culture } \\
\text { fishery }\end{array}$ & Siltation, weeds \\
\hline Karkari Beel & $\begin{array}{l}\text { Potential site for culture } \\
\text { fishery }\end{array}$ & Siltation \\
\hline Sagar Beel & $\begin{array}{l}\text { Potential site for culture } \\
\text { fishery }\end{array}$ & Bad transport \\
\hline Rani Meghna Beel & $\begin{array}{l}\text { Potential site for culture } \\
\text { fishery }\end{array}$ & Bad transport \\
\hline Angang Beel & $\begin{array}{l}\text { Potential site for culture } \\
\text { fishery }\end{array}$ & Weeds \\
\hline Deochhara Beel & $\begin{array}{l}\text { Potential site for fish } \\
\text { stocking }\end{array}$ & Weeds \\
\hline Baua Beel & $\begin{array}{l}\text { Potential site for culture } \\
\text { fishery }\end{array}$ & Siltation, paddy cultivation \\
\hline
\end{tabular}


Table 2 (continued): Potentialities and problems of the wetlands in Assam.

\begin{tabular}{|c|c|c|}
\hline Wetlands & Potentialities & Problems \\
\hline Chatla Haor & $\begin{array}{l}\text { A very big Haor in } \\
\text { Assam, potential site for } \\
\text { fish culture, if water be } \\
\text { retained; IMC and Hilsa } \\
\text { juveniles occur (Plate 5). } \\
\text { Ideal site for } \\
\text { rehabilitation of } \\
\text { displaced fishermen }\end{array}$ & $\begin{array}{l}\text { Siltation, mahajal operation, } \\
\text { tea garden effluents }\end{array}$ \\
\hline Puneer Haor & $\begin{array}{l}\text { Potential site for culture } \\
\text { fishery }\end{array}$ & Tea garden effluents \\
\hline Bakri Haor & $\begin{array}{l}\text { Near the Dhaleswari } \\
\text { River, ideal site for } \\
\text { capture fishery }\end{array}$ & $\begin{array}{l}\text { Siltation, encroachments, } \\
\text { paddy cultivation }\end{array}$ \\
\hline Baskandi Anua & $\begin{array}{l}\text { Potential site for IMC } \\
\text { culture }\end{array}$ & Weeds \\
\hline Algapur Anua & $\begin{array}{l}\text { Potential site for IMC } \\
\text { culture }\end{array}$ & Weeds \\
\hline Silghat Anua & $\begin{array}{l}\text { Potential site for IMC } \\
\text { culture }\end{array}$ & Weeds \\
\hline Rupairbala Anua & $\begin{array}{l}\text { Potential site for IMC } \\
\text { culture }\end{array}$ & Weeds \\
\hline Dungripar Anua & $\begin{array}{l}\text { Potential site for IMC } \\
\text { culture }\end{array}$ & Weeds \\
\hline Satkarakandi Anua & $\begin{array}{l}\text { Potential site for IMC } \\
\text { culture }\end{array}$ & Weeds \\
\hline Ram Nagar Anua & $\begin{array}{l}\text { Potential site for IMC } \\
\text { culture }\end{array}$ & Weeds \\
\hline Fulbari Anua & $\begin{array}{l}\text { Potential site for IMC } \\
\text { culture }\end{array}$ & $\begin{array}{l}\text { Not much weeds, less } \\
\text { problematic }\end{array}$ \\
\hline Sibnarayanpur Anua & $\begin{array}{l}\text { Good site for capture } \\
\text { fishery }\end{array}$ & Siltation, paddy cultivation \\
\hline Ashiali Beel & $\begin{array}{l}\text { Good site for capture } \\
\text { fishery }\end{array}$ & Siltation, paddy cultivation \\
\hline
\end{tabular}




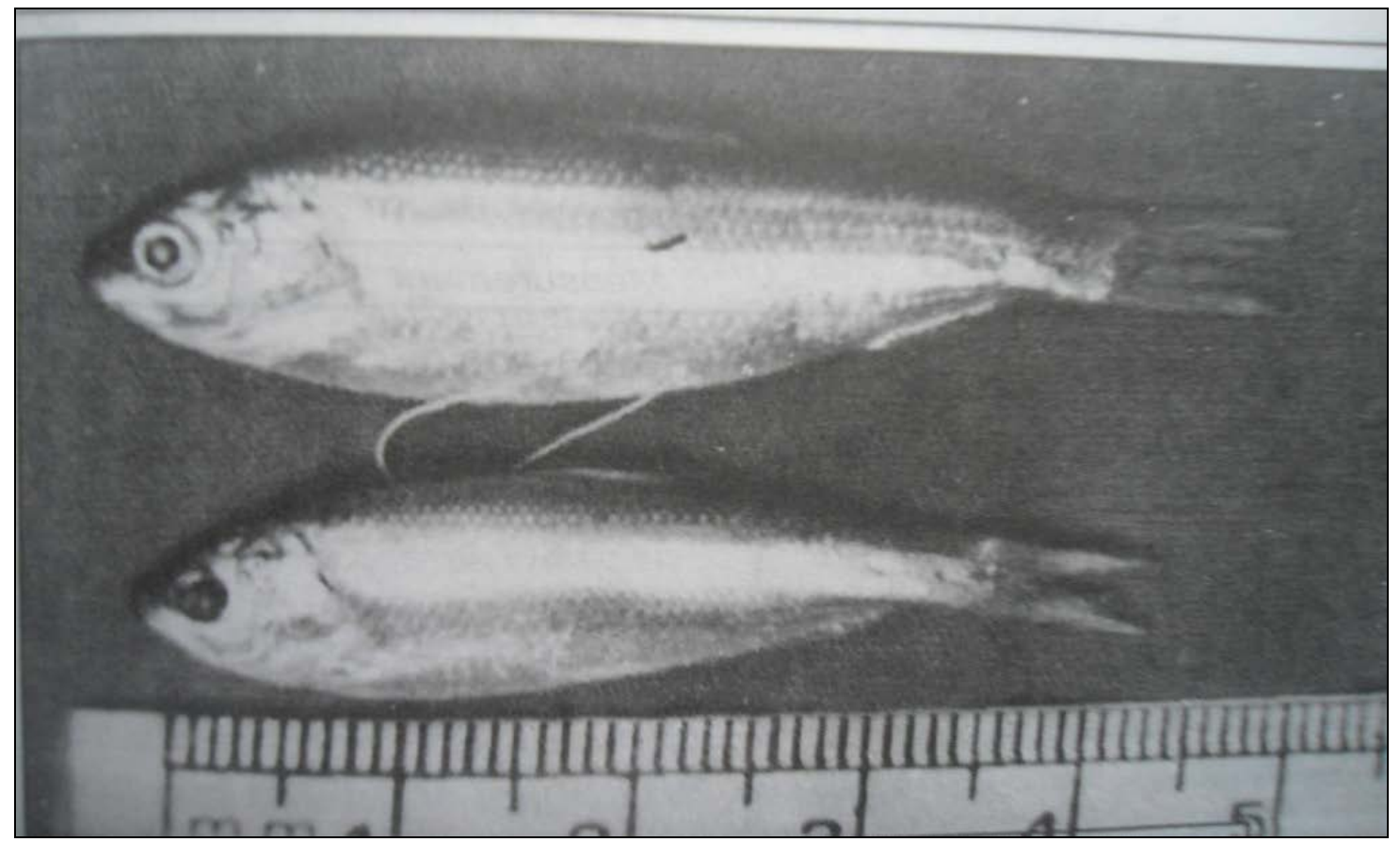

Plate 4: Naturally occurring Hilsa in Sone Beel Wetland of Assam.

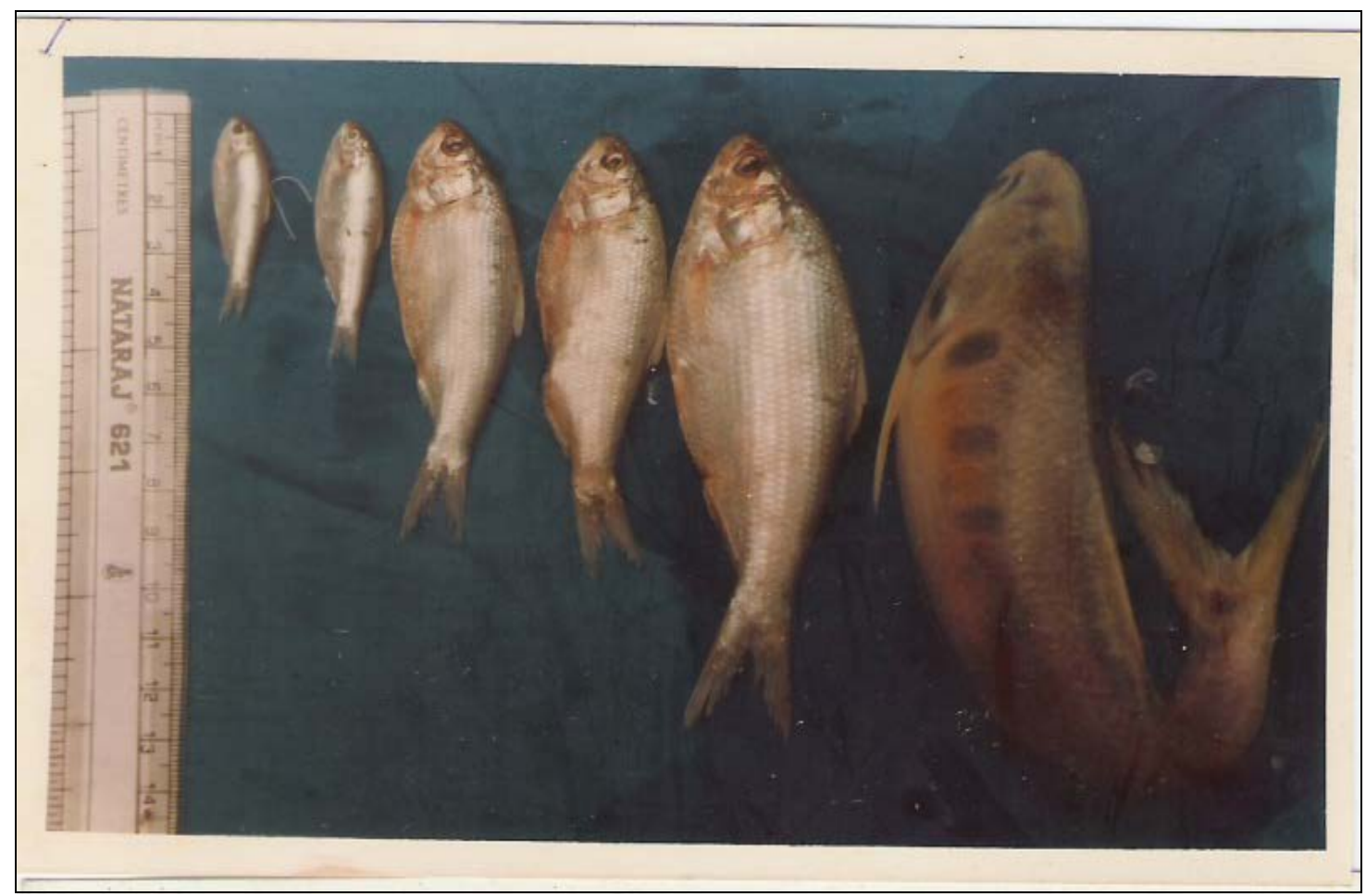

Plate 5: Natural occurrence of Hilsa juveniles in the Chatla Haor wetland in Assam. 


\section{CONCLUSIONS}

Hilsa is a transboundary fish in the international waters, particularly in the Asian continent. Its distribution ranges from Persian Gulf through Pakistan to India, Bangladesh, China, Myanmar (Jayaram, 2010). As such, its natural occurrence in the Sone Beel is highly significant. Further, occurrence of Hilsa juveniles in the Chatla Haor wetland in Assam is of tremendous importance in view of the said biotope, probably, acting as the breeding ground of Hilsa (Kar and Dey, 2002). Such aspects are to be taken due care of at the international level.

Hilsa fish migrate from sea to river for breeding and spawning purpose during monsoon season. However, wetlands support about 77 other fish species assemblages in Barake Valley. Among them, many species also have migratory tendency within freshwater bodies in the river drainage network, and are playing important role for species specific interaction due to different trophic interactions. Many species of cat fishes migrate to these wetlands during flooding season of the river basin for spawning and breeding. Therefore, conclusion has to be revised accordingly, highlighting the overall importance of wetlands.

Shrinkage of water spread area of the wetlands, of late, seems to be a common ailment with them, thus, providing less water availability for the aquatic biota as well as the human population. This matter seems to be a common phenomenon almost throughout the entire Asian continent. Thus, it has to be internationally taken care of.

Likewise, eutrophication of the wetlands seems to be a common disease at the international level, and, hence, has to be taken care of.

Epizootic Ulcerative Syndrome (EUS), the hitherto unknown dreadful, virulent and enigmatic fish disease, which has been sweeping the freshwater fish semi-globally, unabated and unhindered in an epidemic dimension, has been affecting the fish even today. Hence, EUS, causing large-scale mortality of the wetland and the farmed fish, devastating economy and the health of the people, has to be tackled.

The fisher folk are the instruments of fish handling. But, these economically backward and perennially poverty-stricken useful human resources are yet to be rehabilitated properly. As such, this aspect is to be taken care of on a priority basis. 


\section{ACKNOWLEDGEMENTS}

The author utilises the privilege of this opportunity to express his gratitude to the innumerable fisher folk who gave pleasant company and care to the author in many a stormy nights in the strenuous field works by the author spanned over few decades. Their help can, perhaps, neither be returned nor be acknowledged fully. Nevertheless, the author expresses his heartfelt gratitude to all the people involved in this unsanctioned self-financed work (sacrificing his remuneration and leave for long). The author also gratefully acknowledges the tremendous amount of assistance rendered by his student, Mr. Satyajit Das, in the secretarial works. 


\section{REFERENCES}

1. APHA, 1995 - Standard Methods for the Examination of Water and Wastewater, American Public Health Association, USA, xxxix + 1193.

2. Bănăduc D., Rey S., Trichkova T., Lenhardt M. and Curtean-Bănăduc A., 2016 - The Lower Danube River-Danube Delta-North West Black Sea: A pivotal area of major interest for the past, present and future of its fish fauna - A short review, Science of the Total Environment 545-546, 137-151.

3. Banerjea S. M., 1967 - Water quality and soil condition of the fish ponds in some states of India in relation to fish production, Indian Journal of Fish, 14, 1-2, 115-144.

4. Barbhuiya M. H., Kar D. and Goswami U. C., 1999 - Studies on Aquatic Biodiversity of Barak-Nadi Salchapra Oxbow lake in Cachar district of Assam with a note on its Management and Conservation, National Symposium on Trends in Environ-mental biology (23-25 June, 1999), NEHU, Shillong, Abstract, 19.

5. Barbhuiya M. H., Goswami M. M. and Kar D., 2006 - Fishes of Barak Nadi Salchapra Anua with a note on their conservation, Proceedings of the National Conference on Zoology, Pune.

6. Barbhuiya M. H., Goswami M. M. and Kar D., 2007 a - Water quality parameters of Barak Nadi Salchapra Anua wetland in Barak Valley region of Assam, Proceedings of the Indian Science Congress, Annamalai University, Tamil Nadu.

7. Barbhuiya M. H., Goswami M. M. and Kar D., 2007 b - Zooplankton diversity of Salchapra wetland in Cachar district of Assam, Abstracts, All-India Congress of Zoology, 18, 109.

8. Barhoi A., Das S., Das B. K. and Kar D., 2015 - A preliminary survey on the Icthyospecies diversity of Hasila Beel, Urpad Beel, Kumri Beel, Sidli Beel and Seksekia Beel in the Goalpara District of Assam, India, International Journal of Advanced Research, 3, 6, 678684.

9. Bimola M., Singh Shashikumar O., Kar D. and Jajo E., 2014 - A preliminary study on Zooplankton record from Yenapat, a freshwater lake at Bishnupur district, Manipur, NorthEast India, Proceedings of the National Seminar, Recent Advances in fishery science, D. M. College of Science, Manipur, 58-72.

10. Bimola M., Singh Shashikumar O. and Kar D., 2015a - Diversity and abundance of Rotifer in Yenapat Lake of Bishnupur District, Manipur, N. E. India, International Journal of Current Research, 7, 1, 11849-11851.

11. Bimola M., Singh Shashikumar O. and Kar D. 2015 b - Studies on zooplankton community in relation with physico-chemical properties of water of the Yenapat, a freshwater lake at Bishnupur District, Manipur, N. E. India, Life Sciences Bulletin, 11, 2, 153-156.

12. Bimola M., Das U., Das P., Kar S., Singh O. S., Kar D. and Aditya G., 2016b - Rotifer Species Assemblages in Three Freshwater Habitats of Manipur, India, Proceedings of the Zoological Society, Springer, 1-9.

13. Battish S. K. ,1992 - Freshwater Zooplankton of India, Oxford and IBH Publishing Co., Ltd., New Delhi, vi +233.

14. Bennet G. W., 1962 - Management of artificial lakes and ponds, Reinhold (New York), 1283.

15. Biswas K. and Calder C. C., 1955 - Handbook of Common Water and Marsh Plants of India and Burma, 1936), Health Bulletin, 24, Malaria Bureau of Government of India Press (Calcutta), 216.

16. Biswas K. and Calder C. C., 1984 - Handbook of Common Water and Marsh Plants of India and Burma, Bishen Singh Mahendra Pal Singh, Dehra Dun, India, 216. 
17. Callinan R. B., Sammut J. and Fraser G., 1996 - Epizootic Ulcerative Syndrome (Red Spot Disease) in estuarine fish: Confirmation that exposure to acid sulphate soil runoff and an invasive fungus, Aphanomyces sp., are causative factors, Proceedings of the National Conference on Acid Sulphate Soils, Robert J. Smith and Associates and ASSMAC, Australia.

18. CAMP, 1998 - Report of the Workshop on 'Conservation, Assessment and Management Plan (CAMP) for Freshwater Fishes of India', Zoo Outreach Organization and NBFGR, 22-26 Sep., 1997, Lucknow, 156.

19. Chaudhuri H., 1960 - Experiments on induced spawning of Indian carps with pituitary injections, Indian Journal of Fish, 7, 20-48.

20. Choudhury M. H., Das U., Kar S., Das P. and Kar D., 2017a - Analysis of Zooplankton Diversity and Physico-Chemical Parameters of Truncated part of Dhaleswari River Hailakandi, Assam, India, Life Science Leaflets, 88, 30-35.

21. Choudhury A. N., Das P., Das U., Kar S. and Kar D., 2017b - Studies on zooplankton abundance and physico-chemical parameters of Rukni Anua at Bekirpar in Cachar district, Assam, International Journal of Fisheries and Aquatic Studies, 5, 3, 372-374.

22. Chinabut S., Roberts R. J., Willoughby L. G. and Pearson M. D., 1995 - Histopathology of snakehead, Channa striatus (Bloch), experimentally infected with the specific Aphanomyces associated with Epizootic Ulcerative Syndrome (EUS) at different temperatures, Journal of Fish Diseases, 18, 41-47.

23. Chumley J., 1910 - Bibliography of limnological literature, 659-673, in Murray and Pullar’s Bathymatrical Survey of the Scottish Lochs, 1, List of Publications by Forel, 635-689.

24. Cook, R.E., 1977 - Raymond Lindeman and the trophic dynamic concept in ecology, Science, 198, 22-26.

25. Coxton F. E. and Cowden D. J., 1950 - Applied General Statistics, Sir Isaac Pitman and Sons, London, 944.

26. Darlington P. J. (Jr.), 1957 - Zoogeography: The Geographical Distribution of Animals, John Wiley and Sons, New York, 675.

27. Das B and Kar D., 2011 - Essentials of Limnology and Fishery Science, Mangalam Publishers, New Delhi, 190.

28. Das B. K., Chakraborty A. and Kar D., 2013 - Calculation of Length of a Fish using TwoDimensional Geometry, International Journal of Scientific Research, 2, 10, 48-51.

29. Das P. and Kar D., 2013 - Studies on zooplankton diversity and physico-chemical parameters of Ramnagar anua, Cachar, Assam, International Journal of Current Research, 5, 3058-3062.

30. Das P. and Kar D., 2016a - Composition abundance and diversity of zooplankton population from three different wetlands from Barak Valley, Assam, International Journal of Applied and Nature Sciences, 5, 5, 41-46.

31. Das P. and Kar D., 2016b - Biodiversity of Zooplankton in a floodplain lake of the Barak Valley, Assam, North-East, India, International Journal of Advance Research, 4, 4, 906-910.

32. Das P. and Kar D., 2016c - Diversity and abundance of zooplankton in a Temple pond, Barak Valley, Assam, International Journal of Environmental Sciences, 6, 6, 1117-1122.

33. Das P., Mukherjee S., Kar S., Das U., Kar D. and Aditya G., 2018 - Zooplankton as dietary component of selected freshwater fish: network analysis based on gut content, AACL Bioflux, $11,1,232-244$.

34. Das U. and Kar D., 2013 - A comparative study on qualitative and quantitative analysis of zooplankton in relationship with physico-chemical properties of water between Karbala Lake and Baram Baba Pond of Cachar District, Assam, International Journal of Current Research, 5, 3038-3041.

35. Das U. and Kar D., 2014 - Qualitative and quantitative study of planktons including physicochemical properties of water of Assam University Pond, Silchar, Assam, India, Research Frontiers in Wetlands, Fishery and Aquaculture, 247-254, in Research Frontiers in Wetlands, Fishery and Aquaculture, Kar D., (ed.), Dominant Publishers and Distributors Pvt. Ltd., New Delhi, xi +320 . 
36. Das U. and Kar D., 2016a - Studies on biodiversity and spatial distribution of Rotifers, Cladocerans and Copepods from Chatla Haor, a seasonal floodplain wetland of Assam, Lake 2016, International Conference on Conservation and Sustainable Management of Ecologically Sensitive Regions in Western Ghats, The 10th biennial Lake Conference; Alva's College, Moodavidri, Mangalore.

37. Das U. and Kar D., 2016b - Diel and seasonal variation of zooplankton from the freshwater pond of North Tripura District, India, Lake 2016 International Conference on Conservation and Sustainable Management of Ecologically Sensitive Regions in Western Ghats, The 10th biennial Lake Conference; Alva’s College, Moodavidri, Mangalore.

38. Das U. and Kar D., 2016c - Diversity status of zooplankton in a typical pond ecosystem of Cachar District, Assam, India, International Journal of Applied and Natural Sciences, 5, 4, 139-144.

39. Das U. and Kar D., 2016 d - Diversity status of zooplankton in a typical pond ecosystem of Cachar District, Assam, India, International J of Applied and Natural Sciences, 5, 4, 139-144.

40. Das U., Das P., Kar S., Jayapalan C. and Kar D., 2018 - An assessment on zooplankton diversity between three freshwater habitats of Barak Valley, Assam, Uttar Pradesh journal of zoology, 38, 1, 26-34.

41. Day F., 1873 - Report on the freshwater fish and fisheries of India and Burma, Calcutta, 22, 23, 35, 36.

42. Day F., 1878 - The fishes of India, being a natural history of the fishes known to inhabit the seas and freshwaters of India, Burma and Ceylon, Text and Atlas in 4 parts, $\mathrm{W}_{\mathrm{M}}$ Dawson and Sons Ltd., London, $\mathrm{xx}+778$.

43. Day F., 1885 - Relationship of the Indian and African freshwater fish fauna, Journal of the Linnean Society (Zoology), 18, 308-317.

44. Day F., 1889 - The fauna of British India, including Ceylon and Burma: Fishes, I and II, 548 and 509.

45. Devi W. S., Das U., Das P., Kar S. and Kar D., 2017 - Limnological study with emphasis on fish diversity of Loktak Lake, Manipur, India, Bulletin of the Environmental Pharmacology, Life Science, 6, 8, 75-77.

46. Dey S. C.,1973 - Studies on the distribution and taxonomy of the ichthyofauna of the hill streams of Kamrup-Khasi-Garo Regions of Assam with special reference to the functional morphology of some rheophillic fishes, D.Sc. Thesis, University of Calcutta, India, xi + 299.

47. Dey S. C., 1981 - Studies on the hydrobiological conditions of some commercially important lakes (Beels) of Kamrup district of Assam and their bearing on fish production, Final Technical Report, North-Eastern Council, Govt. of India, Shillong, 177.

48. Dey S. C and Kar D., 1985 - Studies on the aquatic macrophytes in Sone, a tectonic lake of Assam, Proceedings of the Indian Science Congress, 72, 67.

49. Dey S. C and Kar D., 1987 - Physico-chemical complexes of water and soil in Sone, an ichthyologically potential tectonic lake of Assam, Journal of the Assam Science Society, 30, 1, $1-11$.

50. Dey S. C and Kar D., 1989 a - Aquatic macrophytes of Lake Sone in Assam, Environment and Ecology, 7, 1, 253-254.

51. Dey S. C and Kar D., 1989 b - Fishermen of Lake Sone in Assam: their socio-economic status, Science and Culture, 55, 395-398.

52. Dey S. C and Kar D., 1989 c - An account of Hilsa ilisha (Hamilton) of Lake Sone in the Karimganj District of Assam, Bangladesh Journal of Zoology, 17, 1, 69-73.

53. Dey S. C. and Kar D., 1989 d - Phytosociology of the aquatic macrophytes of Lake Sone in the Karimganj District of Assam, Proceedings of the Indian Science Congress, 76, 38. 
54. Dey S. C and Kar D., 1990 - Fish Yield Trend in Sone, a tectonic lake of Assam, Matsya, 1516, 39-43.

55. Dey S. and Kar D., 1994 - Phytoplankton dynamics of Lake Sone in Assam, Bulletin of Life Sciences, IV, 49-54.

56. Dhar N., 2004 - Certain aspects of limnology and fishery of Baskandi Lake in the Cachar District of Assam, PhD Thesis, University of Gauhati, Assam,165.

57. Dhar N., Goswami M. M. and Kar D., 2004 - Aquatic macrophytes in Baskandi Lake, an oxbow lake of Barak Basin, Assam, Environment and Ecology, 22, Suplement 4, 606-608.

58. Dutta A., Kar S., Das P., Das U., Das S. and Kar D., 2017 - Studies on physico-chemical aspects and zooplankton diversity of a freshwater wetland in Cachar, Assam, International Journal of Science, Environment and Technology, 6, 3, xx - xx 2277-663X (P).

59. Dutta B., Bailung B., Das B. K., Kar D. and Biswas S. P., 2014 - Ichthyofaunal diversity in the wetlands (Beels) of Charaideo Subdivision, Sivasagar District, Assam and their Health and Management, Environment and Ecology, 32, 1A, 363-367.

60. FAO, 1963 - Modern fishing gears of the world, Proc. 2nd, World Fishing Gear Congress, London.

61. FAO, 1974 - Design of fisheries statistical surveys: Inland Waters, Food and Agricultural Organisation, Fisheries Technical Paper, 133, 1-122.

62. FAO, 1986 - Report of the expert consultation on ulcerative fish diseases in the Asia-Pacific Region, TCP/RAS/4508, Bangkok, 5-9 Aug 1986, FAO Regional office for Asia and the Pacific, Bangkok.

63. Fernando C. H. and Furtado J. J., 1975 - Reservoir fishery resources of South-East Asia, Bulletin of Fisheries Research Station, Sri Lanka, 26, 1-2, 83-95

64. Forel F. A., 1892-1904 - Le Le'man, Monographie limnologique, Lausanne, I-III.

65. Forel F. A., 1895 - Le Le'man, Monographie limnologique, II, Lausanne, 651.

66. Forel F. A., 1901 - Handbuch der Seenkunde. Allgemeine. Limnologie, Stuttgart, 249.

67. Fraser G. C., Callinan R. B. and Calder L. M., 1992 - Aphanomyces species associated with Red Spot Disease: an ulcerative disease of estuarine fish of Eastern Australia, Journal of Fish Diseases, 15, 173-181.

68. Frerichs G. N., Millar S. D. and Roberts R. J., 1986 - Ulcerative Disease Rhabdovirus in Fish in South-East Asia, Nature, 322, 216.

69. Fritsch F. E., 1965 - The structure and reproduction of Algae, II, Phaeophyceae and Myxophyceae, Cambridge University Press, UK.

70. Gadgil M. and Kar D., 2000 - Conserving India’s biodiversity: let people speak, 583-589, in Setting Biodiversity Conservation, 707, World Wide Fund (WWF) for Nature-India, New Delhi.

71. Ghosh S. K. and Lipton A. P., 1982 - Ichthyofauna of the NEH Region with special reference to their economic importance, ICAR Research Complex, NEH Region, Shillong, Special Bulletin, 1, 119-126.

72. Gopal B., Goel P. K., Sharma K. P. and Trivedy R. K., 1981 - Limnological study of a freshwater reservoir, Jamwa Ramgarh (Jaipur), Hydrobiologia, 83, 2, 283-294.

73. Government of Assam, 2006 - Statistical Handbook of Assam, Directorate of Economics and Statistics, Govt. of Assam, Guwahati.

74. Gunther A., 1880 - An introduction to the study of fishes, Adams and Charles Black, Edinburgh, 720.

75. Hamilton B., 1822 - Account of the fishes found in the River Ganges and its tributaries, Edinburgh, UK, 405.

76. Hickling C. F., 1971 - Fish culture, 2nd edition, Faber and Faber, London 317.

77. Henderson S. and Markland H. R., 1987 - Decaying lakes: the origins and control of cultural eutrophication: detailed analysis, John Wiley and Sons, New York, 254.

78. Hooker J. D., 1872 - Flora of British India, I-VI, London. 
79. Hora S. L., 1953 - Fish distribution and Central Asian orography, Current Science, 22, 4, 9394.

80. Hora S. L. and Menon A. G. K., 1952 - Distribution of Indian fishes of the past and their bearing on the geography of India. 1 The extinct freshwater Dipnoan and Ganoid fishes of India, Everyday Science, 1, 26-37.

81. Hora S. L. and Silas E. G., 1952 - Evolution and distribution of glyptosternoid fishes of the Family Sisoridae (Order: Siluroidea), Proceedings of the National Institute of Science, India, 18, 4, 309-322.

82. Hugueny B. and Paugy D., 1995 - Unsaturated fish communities in African rivers, American Naturalist, 146, 162-169.

83. Hutchinson G. E., 1939 - Ecological observations on the fishes of Kashmir and Indian Tibet, Ecological Monograph, 9, 2, 147-181.

84. Hutchinson G. E., 1967 - A treatise on limnology, II, Introduction to lake biology and the limnoplankton, John Wiley and Sons, Inc., New York, ix + 1115.

85. Hutchinson G. E., 1975 - A treatise on limnology, III, Limnological botany, John Wiley and Sons, New York, ix +660 .

86. Jackson M. L., 1973 - Soil chemical analysis, Prentice Hall of India Pvt. Ltd., New Delhi, xiv +498 .

87. Jayaram K. C., 1981 - The freshwater fishes of India, Pakistan, Bangladesh, Burma, Sri Lanka: a Handbook, Zoological Survey of India, Calcutta, xxii +475.

88. Jayaram K. C., 1999 - The Freshwater fishes of the Indian Region, Narendra Publishing House, Delhi, xvii +551 .

89. Jayaram K. C., 2003 - Ecostatus and conservation strategies for Mahseer fishes of India with special reference to Deccan species, 3-12, in Welfare biology in the New Millennium, Kar D., Dey S. C. and Datta N. C., (eds), Allied Publishers Pvt. Ltd., Bangalore, xx + 97.

90. Jhingran V. G., 1991- Fish and fisheries of India, Hindustan Publishing Corporation, New Delhi, xxiii +727 .

91. Kar D., 1984 - Limnology and fisheries of Lake Sone in the Cachar District of Assam, India, PhD Thesis, University of Gauhati, Assam, viii +201.

92. Kar D., 1985 - An overview of the Freshwater fishery in Assam, India, Proceedings of the London Freshwater Group, Queen Marry College, University of London, UK.

93. Kar D., 1990 - Limnology and fisheries of Lake Sone in the Cachar District of Assam (India), PhD Thesis (Published), University of Gauhati, Assam (1984), Matsya 15-16, 209-213.

94. Kar D., 1996 - Biodiversity conservation prioritisation project, WWF (India) - WWF (USA).

95. Kar D., 1999a - Preliminary study of limnology and aquatic biota of Rudra Sagar wetland in South Tripura, Proceedings of the Regional Seminar on Biodiversity, Guwahati, Assam, 1.

96. Kar D. 1999b - Microbiological and environmental studies in relation to fish disease in India, Gordon Research Conference, Connecticut, USA.

97. Kar D., 2000a - Socio-economic development of the fisherwomen through aquaculture with emphasis on integrated farming in the villages around Chatla Haor Wetland in Silchar, Assam. Seminar presented on DBT (Govt. of India)-sponsored Awareness Workshop on biotechnology-based programmes for women and rural development, NEHU, Shillong, 1, 1314.

98. Kar D., 2000b - An account of physico-chemical characteristics of twenty lentic systems in relation to eutrophication status in Barak Valley region of Assam, Proceedings of the National Symposium on Current Trends in Wetlands and Fisheries Research in the New Millennium, 1, 19.

99. Kar D., 2002 - Waterbodies and fishes: resources and development, Conservation Forum Journal, 1, 15. 
100. Kar D., 2003a - Fishes of Barak Drainage, Mizoram and Tripura, 203-211, in Environment, Pollution and Management (eds) Kumar A., Bohra C. and Singh L. K., APH Publishing Corporation, New Delhi, xii +604 .

101. Kar D., 2003b - An account of the fish biodiversity in South Assam, Mizoram and Tripura along with a brief account of Epizootic Ulcerative Fish Disease Syndrome in freshwater fishes. UGC-sponsored Invited Lecture in Dept. of Environmental Engg., Guru Jambeswar University, Hissar, Haryana.

102. Kar D., 2003c - Peoples' perspective on fish conservation in the water bodies of South Assam, Mizoram and Tripura, 325-328, in Participatory approach for fish biodiversity conservation in North-East India (eds) Mahanta P. C. and Tyagi L. K., National Bureau of Fish Genetic Resources (ICAR), Lucknow, v + 412.

103. Kar D., 2005 - Fish diversity in the major rivers in Southern Assam, Mizoram and Tripura, 679-691, Proceedings of 2nd International Symposium on GIS and Spatial Analyses in Fisheries and Aquatic Sciences, 2-6 Sep 2002, University of Sussex, Brighton (UK), (eds), 2, Nishida T., Kailola P. J. and Hollingworth C. E., Fisheries and Aquatic GIS Research Group, Kawagoe, Saitama, Japan.

104. Kar D., 2006a - Panorama of wetlands in North-East India with special emphasis on their eutrophication status, Science and Society, 4, 2, 167-180.

105. Kar D., 2006b - Study of fish diversity in a wetland, Activity Guide "Biodiversity”, 37-38, National Childrens' Science Congress, NCSTC Network and Department of Science and Technology, Government of India.

106. Kar D., 2007a - Fundamentals of limnology and aquaculture biotechnology, Daya Publishing House, New Delhi, xiv +609 .

107. Kar D., 2007b - Lentic fishery: fishery of a tropical wetland (Beel) in Assam, Science and Society, 5, 1, 53-72.

108. Kar D., 2010a - Water bodies, fish diversity and sustainable aquaculture, Annual Journal of Womens’ College, Silchar, Assam, 168-194.

109. Kar D., 2010b - Biodiversity Conservation Prioritisation, xi + 167, Swastik Publications (New Delhi), ISBN: 978-93-80138-26-8.

110. Kar D., 2010c - Present status of fish diversity and water bodies in North-East India with a note on their conservation, keynote address of the session chair, Lake 2010 International Conference, Indian Institute of Science, Bangalore, December 2010.

111. Kar D., 2011a - Panorama of wetlands, rivers and fishes of North-East India with a note on the health of fishes. Proceedings of International Symposium on Ecological Sciences, Kerala University, 9-10 November 2011.

112. Kar D., 2011b - Fish diversity, fish habitats, fish disease and aquaculture in North-East India hotspot: A synopsis, Conservation Forum Journal, 3, 5.

113. Kar D., 2012a - Wetlands, rivers, fish diversity, Fish disease and aquaculture in North-East India, Fishing Chimes, 31, 12, 35-37.

114. Kar D., 2012b - Essentials of fish biology, Dominant Publishers, (New Delhi), vii + 244.

115. Kar D., 2012c - Taxonomy, BSc, MSc, NET, SLET, APH Publications (New Delhi), 102.

116. Kar D., 2013a - Wetlands and lakes of the world, Springer, London, Print ISBN 978-81-3221022-1, e-Book ISBN: 978-81-322-1923-8, xxx + 687.

117. Kar D., 2013b - Wetlands, rivers and fishes of North-East India with a note on the health of fishes, Proceedings of International Symposium, Kerala University, 3-5 October 2013.

118. Kar D., 2014a - Wetlands of Assam with special reference to Sone Beel, the biggest wetland in Assam and MoEF-Listed Wetland of National Importance, Research Frontiers in Wetlands, Fishery and Aquaculture, 19-42, in Research Frontiers in Wetlands, Fishery and Aquaculture, (ed.) Kar D., Dominant Publishers and Distributors Pvt. Ltd., New Delhi, xi + 320. 
119. Kar D., 2014b - Epizootic Ulcerative Syndrome Disease in wetland fishes, Research Frontiers in Wetlands, Fishery and Aquaculture, 43-58, in Research Frontiers in Wetlands, Fishery and Aquaculture (ed.) Kar D., Dominant Publishers and Distributors Pvt. Ltd., New Delhi, xi + 320.

120. Kar D., 2014c - Research Frontiers in Wetlands, Fishery and Aquaculture, Dominant Publishers and Distributors Pvt. Ltd., New Delhi, xi + 320.

121. Kar D., 2015 - Epizootic Ulcerative Fish Disease Syndrome, Elsevier, Academic Press, USA, $\mathrm{xix}+293,314$.

122. Kar D., 2016a - Wetlands, Rivers, Fish Resources and Fish Disease in North-East India: An Overview, Proceedings of International Symposium on Aquaculture and Fisheries (as part of the International Conference on Environmental Sustainability for Food Security (ENFOSE, 2016), 23 September 2016, held at Fisheries College and Research Institute (FCRI), Tamil Nadu Fisheries University (TNFU), 6.

123. Kar D., 2016b - Wetlands, rivers, fish, plankton resources and fish disease and aquaculture in North-East India: an overview, Proceedings of International Symposium, Lake 2016, 37, Indian Institute of Science, Bengaluru, and Alva’s Education Foundation, India.

124. Kar D and Barbhuiya A. H., 2008 - Panorama of wetlands, rivers and fish diversity in NorthEast India with a glimpse on fish health, in Fish and Fisheries (eds) Pandey B. N., Trivedy S. P., Kamal J., Kaur Sethi N., Sarup Book Publishers, New Delhi, 263.

125. Kar D. and Barbhuiya A. H., 2013 - Frontiers of wetlands, fishers and aquaculture research, Mangalam Publications, New Delhi, 263.

126. Kar D. and Barbhuiya M. H., 2000a - Length-weight relationship and condition factor in Gudusia chapra (Hamilton-Buchanan) and Botia dario (Hamilton-Buchanan) in Chatla Haor (Floodplain Wetland) in Cachar District of Assam, Environment and Ecology, 18, 1, 227-229.

127. Kar D. and Barbhuiya M. H., 2000b - Ichthyodiversity of Chatla Haor: a floodplain wetland in Barak Valley region of Assam, 3-6, in Advances in Zoology and Environmental Degradation and Biodiversity, (eds) Pandey B. N. and Singh B. K., Daya Publishing House, New Delhi, 279.

128. Kar D and Barbhuiya M. H., 2000c - Studies on the abundance and Diversity of Zooplankton in Chatla Haor: a floodplain wetland in Cachar District of Assam, Proceedings of National Symposium Current Trends in Wetlands and Fisheries Research in the New Millennium, 1, 11.

129. Kar D. and Barbhuiya M. H., 2000d - Water bodies and fishes: resources and development, National Symphosium, Current Trends in Wetlands and Fisheries Research in the New Millennium, 1, 25.

130. Kar D and Barbhuiya M. H, 2001 - Ecology of Aquatic Macrophytes of Chatla Haor, a floodplain wetland in Cachar District of Assam, Environment and Ecology, 19, 1, 231-233.

131. Kar D. and Barbhuiya M. H., 2002a - Macrophytic diversity in certain wetlands of Barak Valley region of Assam, 86-89, in Restoration of lakes and wetlands (eds) Ramachandra T. V., Rajasekara Murthy N. and Ahalya N., Allied Publishers (P) Ltd., Bangalore, xxii + 400.

132. Kar D. and Barbhuiya M. H., 2002b - Waterfowls in Chatla Haor, a seasonal floodplain in Cachar District of Assam with a note on waterfowl and wetland conservation, Environment and Ecology, 20, 3, 689-691.

133. Kar D. and Barbhuiya M. H., 2002c- Aquatic macro-invertebrates of Baraknadi Salchapra Anua in Barak Valley Region of Assam, Environment and Ecology, 20, 2, 696-699.

134. Kar D. and Barbhuiya M. H., 2004 - Abundance and diversity of zooplankton in Chatla Haor, a floodplain wetland in Cachar District of Assam, Environment and Ecology, 22, 1, 247-248.

135. Kar D. and Dey S. C., 1982a - Hilsa ilisha (Hamilton) from Lake Sone in Cachar, Assam, Proceedings of Indian Science Congress, 69, 77. 
136. Kar D. and Dey S. C., 1982b - An account of Hilsa ilisha (Hamilton) of Sone Beel (Cachar district, Assam, India), Proceedings of All-India Seminar of Ichthyology, 2, 3.

137. Kar D. and Dey S. C., 1986 - An account of ichthyospecies of Lake Sone in Barak Valley of Assam, Proceedings of All-India Seminar, Ichthyology, 2, 3.

138. Kar D. and Dey S. C.,1987 - An account of the fish and fisheries of Lake Sone in the Barak Valley of Assam (India), Proceedings of Workshop Development of Beel Fisheries in Assam, $1,13$.

139. Kar D. and Dey S. C., 1988a - A critical account of the recent fish disease in the Barak Valley of Assam, Proceedings of Regional Symposium on Recent outbreak of Fish Diseases in North-East India, 1, 8.

140. Kar D. and Dey S. C., 1988b - Impact of recent fish epidemics on the fishing communities of Cachar District of Assam, Proceedings of Regional Symposium on Recent outbreak of Fish Diseases in North-East India, 1, 8.

141. Kar D. and Dey S., 1988c - Preliminary electron microscopic studies on diseased fish tissues from Barak Valley of Assam, Proceedings of Annual Conference of Electron Microscopic Society of India, 18, 88.

142. Kar D. and Dey S. C., 1988d - An account of fish yield from Lake Sone in the Barak Valley of Assam, Proceedings of Indian Science Congress, 75, 49.

143. Kar D. and Dey S. C., 1990a - Fish disease syndrome: a preliminary study from Assam, Bangladesh, Journal of Zoology, 18, 115-118.

144. Kar D. and Dey S. C., 1990b - A preliminary study of diseased fishes from Cachar District of Assam, Matsya, 15-16: 155-161.

145. Kar D. and Dey S. C., 1990c - Epizootic Ulcerative Syndrome in Fishes of Assam, Journal of Assam Scientific Society, 32, 2, 29-31.

146. Kar D. and Dey S. C., 1990d - An account of the Indian major carps of Lake Sone in Assam, Proceedings of Indian Science Congress, 77, 70.

147. Kar D. and Dey S. C., 1990e - Interrelationship and dynamics of fish population of Lake Sone in Assam, Proceedings of Indian Science Congress, 77, 69.

148. Kar D. and Dey S. C., 1993 - Interrelationship and dynamics of fish population of Lake Sone in Assam, Environment and Ecology, 11, 3, 718-719.

149. Kar D. and Dey S. C., 1995 - Scooping gears of Lake Sone in Assam, Proceedings of Indian Science Congress, 82.

150. Kar D. and Dey S. C., 1996 - Zooplankton dynamics of Lake Sone in Assam, Proceedings of Indian Science Congress, 83, III, 14.

151. Kar D. and Dey S. C., 2000a - A brief account of the limnology and fishery of Sone Beel, the biggest wetland in Assam, Proceedings of Natural Symposium, Wetlands and Fisheries Research in the New Millennium, 1, 17.

152. Kar D. and Dey S. C., 2000b - Yield and conservation of Indian major carps of Lake Sone in Assam, Environment and Ecology, 18, 4, 1036-1038.

153. Kar D. and Dey S. C., 2000c - An overview of the fish diseases in India with special emphasis on Epizootic Ulcerative Syndrome, Proceedings of International Symposium, Lake 2000, Indian Institute of Science, Bangalore, 1, 21.

154. Kar D. and Dey S. C., 2002 - On the occurrence of advanced fry of Hilsa (Tenualosa) ilisha (Hamilton-Buchanan) in Chatla Haor Seasonal Wetland of Assam, Proceedings of Zoology Society, Calcutta, Springer, 55, 2, 15-19.

155. Kar D. and Sen N., 2007 - Systematic list and distribution of fish biodiversity in Mizoram, Tripura and Barak drainages in North-East India, ZOOs’ Print Journal, 22, 3, 2599-2607.

156. Kar D. and Upadhyaya T., 1998 - Histopathological studies of fish tissues affected by Epizootic Ulcerative Syndrome in Assam, Technical Bulletin, XIII Convention and National Symposium of Indian Association of Veterinary Anatomists (IAAM), 11-13 Dec 1998, College of Veterinary Sciences, Assam Agricultural University, Guwahati. 
157. Kar D., Dey S. C., Michael R. G., Kar S. and Changkija S. 1990 - Studies on fish epidemics from Assam, India, Journal of Indian Fisheries Association, 20, 73-75.

158. Kar D., Dey S. C., Kar S., Bhattacharjee N. and Roy A., 1993 - Virus-like particles in Epizootic Ulcerative Syndrome of fish, Proceedings of International Symposium on VirusCell Interaction: Cellular and Molecular Responses, 1, 34.

159. Kar D., Dey S. C., Kar S., Roy A., Michael R. G., Bhattacharjee S. and, Changkija S., 1994 A candidate virus in Epizootic Ulcerative Syndrome of Fish, Proceedings of National Symposium of the Indian Virological Society, 1, 27.

160. Kar D., Dey S. C. and Kar S., 1994b - Variegated Encircling gears in Lake Sone of Assam, Proceedings of Indian Science Congres, 81, 64.

161. Kar D., Roy A., Dey S. C., Menon A. G. K. and Kar S., 1995a - Epizootic Ulcerative Syndrome in fishes of India, World Congress of in Vitro Biology, In Vitro, 31, 3, 7.

162. Kar D., Kar S., Roy A. and Dey S. C., 1995b - Viral Disease Syndrome in fishes of NorthEast India, Proceedings of International Symposium of International Centre for Genetic Engineering and Biotechnology (ICGEB) and the University of California at Irvine, 1, 14.

163. Kar D., Dey S. C. and Kar S., 1995c - Lake Sone in Assam and its Biodiversity, Xth Annual Congress on Man and Environment, National Environment Science Academy and National Institute of Oceanography, 10, 52.

164. Kar D., Dey S. C. and Kar S., 1995d - Fish and fisheries of Lake Sone in Assam, Journal of North-Eastern Council, 15, 2-3, 49-57.

165. Kar D., Dey S. C., Kar S. and Roy A., 1995e - Epizootic Ulcerative Disease Syndrome among the fishes of North-East India, Journal of North-Eastern Council, 14, 4, 21-24.

166. Kar D., Dey S. C., Purkayastha M. and Kar S., 1996a - An overview of the impediments in conservation of biodiversity of Lake Sone in Assam, Proceedings of Seminar on Conservation of Biodiversity in Indian Aquatic Ecosystems, 1, Jawahar Lal Nehru University, New Delhi.

167. Kar D., Dey S. C., Kar S. and Michael R. G. and Gadgil M., 1996b - Ichthyoecology, management and conservation of fish resources of Lake Sone in Assam (India), Tiger Paper (Food and Agricultural Organisation of the United Nations), XXIII, 3, 27-32.

168. Kar D., Purkayastha M. and Kar S., 1996c - Biodiversity Conservation Prioritisation Project: A case study from Sone Beel in Assam, Proceedings of National Workshop on Biodiversity Conservation Prioritisation Project (BCPP), World Wide Fund (WWF) for Nature-India and Centre for Ecological Sciences, Indian Institute of Science, Bangalore.

169. Kar D., Dey S. C. and Kar S., 1996d - An account of the trawls of Lake Sone in Assam, Proceedings of Indian Science Congress, 83, III, 14-15.

170. Kar D., Purkayastha M. and Kar S., 1996e - Biodiversity Conservation Prioritisation Project: A case study from Sone Beel in Assam, Proceedings of National Workshop on Biodiversity Conservation Prioritisation Project (BCPP), 1, World Wide Fund (WWF) for Nature-India and Centre for Ecological Sciences, Indian Institute of Science, Bangalore.

171. Kar D., Saha D., Laskar R. and Barbhuiya M. H., 1997 - Biodiversity Conservation Prioritisation Project (BCPP) in Barak Valley Region of Assam, Proceedings of National Project Evaluation Workshop on BCPP, 1, Betla Tiger Reserve and National Park, Palamu.

172. Kar D., Purkayastha M. and Dey S. C., 1998a - An account of the avifauna of Lake Sone in Assam, Proceedings of Indian Science Congress, 85, III, 2.

173. Kar D., Dey S. C. and Kar S., 1998b - An account of the littoral macro-fauna of Lake Sone in Assam, Proceedings of Indian Science Congress, 85, III, 2-3.

174. Kar D., Barbhuiya M., Barbhuiya M. H. and Saha D., 1998c - Wetland birds of Sat Beel in Cachar District of Assam, Proceedings of Indian Science Congress, 85, III, 4. 
175. Kar D., Saha D., Barbhuiya R. L., Barbhuiya M. H., Kar S. and Dey S. C., 1999a Limnological studies of some of the wetlands of Assam, Mizoram, Tripura and Arunachal Pradesh related to their status of Eutrophication, Proceedings of Indian Science Congress, 86, III, 55.

176. Kar D., Rahaman H., Barnman N. N., Kar S., Dey S. C. and Ramachandra T. V., 1999b Bacterial pathogens associated with Epizootic Ulcerative Syndrome in freshwater fishes of India, Environment and Ecology, 17, 4, 1025-1027.

177. Kar D., Mandal M. and Bhattacharjee S., 1999c - Fungal pathogens associated with Epizootic Ulcerative Syndrome in fishes of Barak Valley region of Assam, Proceedings of $1^{\text {st }}$ National Conference on Fisheries Biotechnology, Central Institute of Fisheries Education (CIFE), 1, 34.

178. Kar D., Mandal M., Laskar B. A., Dhar N. and Barbhuiya M. H., 2000a - Ichthyofauna of some of the oxbow lakes in Barak Valley region of Assam, Proceedings of the National Symposium on Wetlands and Fisheries Research in the New Millennium, 1, 16.

179. Kar D., Mandal M., Laskar B A. and Das P., 2000b - On a collection of fishes from some of the lentic systems in Barak Valley of Assam, Proceedings of the National Symposium on Wetlands and Fisheries Research in the New Millennium, 1, 17.

180. Kar D., Das S., Das S., Das Talukdar A., Das S., Datta J. and Upadhyay H., 2000c - A collection of fishes from Hatkhal Beel in Rongpur Village of Silchar City in Assam, Proceedings of the National Symposium on Wetlands and Fisheries Research in the New Millennium, 1, 33.

181. Kar D., Barbhuiya M. H. and Goswami U. C., 2000d - Phytoplankton diversity of Chatla Haor, a floodplain wetland in Cachar District (Assam), Regional Seminar on Recent Trends in Zoology, 14 Sep 2000, NEHU, Shillong Abstracts, 18.

182. Kar D., Dey S. C., Roy A. and Mandal M., 2000e - Epizootic Ulcerative Syndrome Fish Disease in Barak Valley region of Assam, India, Proceedings of the National Symposium on Wetlands and Fisheries Research in the New Millennium, 1, 2.

183. Kar D., Dey S. C., Roy A. and Mandal M., 2002 - Epizootic Ulcerative Syndrome in Fishes of Barak Valley of Assam, India, 303-307, in Restoration of Lakes and Wetlands (eds) Ramachandra T. V., Murthy Rajasekhara S. and Ahalya N., Allied Publishers (P) Ltd. Bangalore, xii +400 .

184. Kar D., Dey S. C. and Datta N. C., 2003a - Welfare Biology in the New Millennium, Allied Publishers Pvt. Ltd., Bangalore, $\mathrm{xx}+97$.

185. Kar D., Dey S. C., Roy A. and Mandal M., 2003b - Epizootic Ulcerative Syndrome Fish Disease in Barak Valley Region of Assam, 73-78, in Welfare biology in the new millennium (eds) Kar D., Dey S. C. and Datta N. C., Allied Publishers Pvt. Ltd., Bangalore, xx + 97.

186. Kar D., Nagarathna A. V., Ramachandra T. V. and Dey S. C., 2006a - Fish diversity and conservation aspects in an aquatic ecosystem in North-East India, ZOOS' Print Journal, 21, 7, 2308-2315.

187. Kar D., Mazumdar J., Devi P., Devi B. R. and Devi V., 2006b - Isolation of Aeromonas hydrophila from fishes affected by Epizootic Ulcerative Syndrome as well as from corresponding healthy fish species and from their habitat, Journal of Current Sciences, 9, 1, 323-327.

188. Kar D., Barbhuiya A. H. and Saha B., 2007a - Panorama of wetland diversity in South Assam, Abstracts in National Conference on Wetlands, Science and Society: An assessment of their integration: Ministry of Environment, Forests and Climate change, Government of India and University of Delhi, 48-50.

189. Kar D., Mazumdar J., Halder I. and Dey M., 2007b. - Dynamics of initiation of disease in fishes through interaction of microbes and the environment, Current Science, Bangalore, 92, 2, 177-179.

190. Kar D., Mazumdar J. and Barbhuiya M. A., 2007c - Isolation of Mycotic flora from fishes affected by Epizootic Ulcerative Syndrome in Assam, India., Asian Journal of Microbiology and Biotechnology, 9, 1, 37-39. 
191. Kar D., Barbhuiya A. H., and Das B., 2008a - Fish diversity and Epizootic Ulcerative Syndrome Fish Disease in India, Key Speaker, International Meet of Asian Fisheries Forum, Central Inland Fisheries Research Institute (CIFRI), Calcutta.

192. Kar D., Barbhuiya A. H. and Das B., 2008b - Wetlands, rivers and fish diversity in North-East India, Key Speaker at International Symposium of Indian National Cartographic Association, Indian Space Research Organisation (ISRO), Ahmedabad, November 2008.

193. Kar D., Barbhuiya A. H., Thangjam G., Devi S. M., Deb S., Das B., Chanu H. and Nishima H., 2008c - Panorama of fish biodiversity in certain rivers and wetlands in Manipur, Proceedings of Zoological Society, India, 7, 2, 123-134.

194. Kar D., Barbhuiya A. H., Baruah A. R., Choudhury C., Banerjee P., Pal R., Bhattacharjee A., Saikia R., Das B., Barman R. and Saha B., 2009 - Panorama of fish diversity in certain rivers, wetlands and protected areas in Assam, Geobios, 36, 57-64.

195. Kar D., Sharma R., Das B. and Barbhuiya A. H., 2010 - An overview of the Wetlands, rivers and fishes in North-East India with a brief note on their present status using GIS tools, 151164, in Biodiversity and Human Welfare, (eds), Goswami U. C., Sharma D. K., Kalita J. and Saikia P. K., Narendra Publishing House, New Delhi.

196. Kar D., Bharbhuiya A. H. and Saha B., 2014 - Panorama of wetland diversity in South Assam, Frontiers of Wetlands, Fishers and Aquaculture Research, 187-210, in Research Frontiers in Wetlands, Fishery and Aquaculture, (eds) Kar D., Dominant Publishers and Distributors Pvt. Ltd., New Delhi, xi + 320.

197. Kar D., Singha R., Das B. K., John R., George R., Mansoor M. and Selva M., 2015 Preliminary epidemiological studies on Epizootic Ulcerative Syndrome (EUS) in freshwater fishes of Assam, International Journal of Scientific Research in Science, Engineering and Technology, 1, 5, 256-263.

198. Kar S. and Kar D., 2013 - Studies on zooplankton diversity of an Oxbow lake of South Assam, India, International Journal of Current Research, 5, 9, 3412-3417.

199. Kar S. and Kar D., 2014 - Ecology of four wetlands in South Assam: a comparison, 239-246, in: Research Frontiers in Wetlands, Fishery and Aquaculture, (ed.) Kar D., Dominant Publishers and Distributors Pvt. Ltd., New Delhi, xi + 320.

200. Kar S. and Kar D., 2016a - Zooplankton diversity of a freshwater pond in Cachar District of Assam, India, International Journal of Life Sciences, 4, 1, 125-128.

201. Kar S. and Kar D., 2016b - Zooplankton diversity of a freshwater perennial pond in Silchar city of Assam, India, American International Journal of Research in Formal, Applied and Natural Sciences, 14, 1, 10-14.

202. Kar S. and Kar D., 2016c - Zooplankton diversity of a freshwater pond in Cachar District of Assam, India, International Journal of Life Sciences, 4, 1, 125-128.

203. Kar S. and Kar D., 2016d - Zooplankton diversity in a freshwater lake of Cachar, Assam, International Journal of Applied Biology and Pharmaceutical Technology, 7, 1, 301-305.

204. Kar S. and Kar D., 2016e - Zooplankton diversity of a freshwater wetland of Assam, International Journal of Advanced Biotechnology and Research, 7, 2, 614-620.

205. Kar S. and Kar D., 2016f - Seasonal variations of zooplankton in a perennial water body of Silchar City, Assam, Lake 2016, Conference on conservation and sustainable management of ecologically sensitive regions in Western Ghats, The 10th biennial Lake Conference, Indian Institute of Science and Alva's College, Moodavidri, Mangalore.

206. Kar S., Das P., Das U., Bimola M., Kar D. and Aditya G., 2017 - Culture of the zooplankton as fish food: observations on three freshwater species from Assam, India, AACL Bioflux, 10, 5, 1210-1220. 
207. Kar S., Das P., Das U., Bimola M., Kar D. and Aditya G., 2018 - Correspondence of zooplankton assemblage and water quality in wetlands of Cachar, Assam, India: Implications for environmental management, Limnological Review, 18, 1, 9-19.

208. Laskar B. A., Das S., Nath D. and Kar D., 2002 - Ecological studies in Puneer Haor Wetland in Cachar District of Assam with special emphasis on Aquatic macrophytes, ichthyofauna and wetland birds, Conservation Forum Journal, 1, 25.

209. Laskar M. F., Kar S., Das P., Das U., Das S. and Kar D., 2017 - Analysis of zooplankton diversity and limnological parameters of Salchapra Anua, an oxbow lake in Silchar, Assam, Journal of Environmental Science, Toxicology and Food Technology, 6, III, 12-15.

210. Le Cren E. D., 1951 - The Length-Weight relationship and seasonal cycle in gonad weight and condition of perch (Perca fluviatilis), Journal of Animal Ecology, 21, 210-219.

211. Lilley J. H., Hart D., Richards R. H., Roberts R. J., Cerenius L. and Söderhäll K., 1997 - PanAsian spread of single fungal clone results in large-scale fish-kills, Veterinary Record, 140, 653-654.

212. Menon A. G. K., 1955 - The external relations of Indian freshwater fishes with special reference to the countries bordering the Indian ocean, Journal of Asiatic Sciences, 21, 2, 3138.

213. Menon A. G. K., 1973 - Origin of the freshwater fish fauna of India, Current Science, 42, 16, 553-556.

214. Menon A. G. K., 1974 - A checklist of the fishes of the Himalayan and the Indo-gangetic Plains, Inland Fisheries Society, India, Barrackpore, viii +136.

215. Menon A. G. K., 1988 - Conservation of the Ichthyofauna of India, 55-33, in Conservation and Management of the Inland Capture Fisheries Research Bulletin, 57, Central Inland Capture Fisheries Research Institute, Barrackpore.

216. Menon A. G. K., 1994 - Criteria for determining the status of threatened categories of Indian freshwater fishes, 1-5, in Threatened Fishes of India, Natcon Publication, 4, 384, UP.

217. Menon A. G. K., 1999 - Checklist: freshwater fishes of India, Occasional Paper, 175, Zoological Survey of India, Calcutta, xviii +366.

218. Misra K. S., 1976 - The Fauna of India and the adjacent countries: Pisces, $2^{\text {nd }}$ edit.: 3. Teleostomi: Cypriniformes, Siluri, 387.

219. Mookerjee H. K., 1945 - Life history of some major carps of Bengal, Scientific and Culture, 10, 9, 400-402.

220. Motwani M. P., Jayaram K. C., and Sehgal K. L., 1962 - Fish and fisheries of Brahmaputra River system, Assam, I, Fish fauna with observation on their zoogeographical significance, Tropical Ecology, 3, 17-43.

221. Moyle P. B., 1976 - Fish introduction in California, history and impact on native fishes, Biological Conservation, 9, 101-118.

222. Myers G. S., 1949 - Salt tolerance of freshwater fish groups in relation to geographical problems, Bijdr tot de Dierk, 28, 315-322.

223. Narzary A., Das S., Das B. K., Singh Ng. R., Kar S., Das P., Dutta B. and Kar D., 2015 - A preliminary study on zooplankton diversity of Ramnagar Anua, Srikona Beel and Tapang Haor of Cachar District, Assam, India: a project report, Journal of Chemical, Biological and Physical Sciences (An international peer review E-3 Journal of Sciences), 5, 3, 2809-2817.

224. Nath P. and Dey S. C., 2000 - Conservation of fish germplasm resources of Arunachal Pradesh, 49-67, in Fish biodiversity of North-East India (eds.) Ponniah A. G. and Sarkar U. K., NATP Publication 2, National Bureu of Fish Genetic Resources (NBFGR), Lucknow, xiii $+228$.

225. Nautiyal P. and Lal M. S., 1981 - Recent records of Garhwal Mahseer (Tor putitora) with a note on its present status, Journal of the Bombay Natural History Society, 79, 593-595.

226. Nelson J. S., 1994 - Fishes of the World, 600, 3rd Ed. John Wiley and Sons, USA.

227. Nichols J. T., 1928 - Fishes of the White Nile (with table of World's freshwater fish faunae), American Museum Novitates, 319. 
228. Ogale S. N., 1994 - Endangered Deccan Mahseer, Tor khudree (Sykes): A case Study, 213218, in Threatened Fishes of India, Natcon. Publication, 4, 384, UP.

229. Pearsall W. H., 1938 - The Soil complex in relation to Plant communities, I. Oxidationreduction potentials in soils, Journal of Ecology, 26, 180-193.

230. Pennak R. W., 1953 - Freshwater invertebrates of the United States, The Roland Press Co., New York, ix +769 .

231. Pillay T. V. R. and Ghosh A. N., 1958 - A note on hilsa fisheries of Assam, Journal of the Bombay Natural History Society, 55, 174-177.

232. Ramsar Convention Secretariat, 2004 - Ramsar handbooks for wide use of wetlands. $2^{\text {nd }}$ Edition, Ramsar Convention Secretariat, Gland, Switzerland.

233. Riji J. K., Rosalind M., Kar D., Md, Mansoor, Kumar, Mahesh., Singha, Ratnabir, Waikhom, Gushein Z., 2016 - Detection of Ranavirus infection in cultivated carps of North-East India, Fish Pathology, 51, special issue, 66-74.

234. Roberts R. J. (ed.), 1978 - Fish pathology, Bailliere Tindall, London, x + 318.

235. Roberts R. J., Frerichs G. N. and Millar S. D., 1992 - Epizootic Ulcerative Syndrome: the current position, 431-436, in Diseases in Asian Aquaculture: I. (eds) Shariff I. M., Subasinghe R. P. an, Arthur J. R., Fish Health Section, Asian Fisheries Society, Manila, The Philippines. x +318 ,

236. Sarwar, Ahmed and Kar D., 2016 - Study of physico-chemical and biological features of Junamara, Karkari, Shundarkoi, Moichatal and Chatrodoria Beels in Katigorah, Cachar, Assam, Indian Journal of Applied Research, 6, 8.

237. Schopf J. W. (ed.) 2002 - Life's origin: the beginnings of biological evolution. University of California Press, ISBN 0-520-23391-3, A recent survey of the field, 208.

238. Sehgal K. L., 1994 - State-of-Art of Endangered, Vulnerable and Rare Coldwater Fishes of India, 127-135, in Threatened Fishes of India, Natcon Publication, 4, 384, UP.

239. Sen N., 1982 - Studies on the systematics, distribution and ecology of the ichthyofauna of Meghalaya and their bearing on the fish and fisheries of the state, PhD Thesis, University of Gauhati, Assam, vi +576 .

240. Sen T. K., 1985 - The fish fauna of Assam and the neighbouring North-Eastern states of India, Records of Zoological Survey of India, Occasional Paper, 64, 1-216.

241. Sen N., 2000 - Occurrence, distribution and status of diversified fish fauna of North-East India, 31-48, in Fish Diversity of North-East India (eds) Ponniah A. G. and Sarkar U. K., National Bureau of Fish Genetic Resources (NBFGR), ICAR, Lucknow, 228.

242. Shaw G. E. and Shebbeare E. O., 1937 - The fishes of Northern Bengal, Journal of the Royal Asiatic Society of Bengal, Science, 137.

243. Silas E. G., 1952 - Further studies regarding Hora’s Satpura Hypothesis, (2) Taxonomic assessment and levels of evolutionary divergence of fishes with the so-called Malayan affinities in Peninsular India, Proceedings of the National Institute of Sciences of India, 18, 5, 423-448.

244. Singh N. R., Das B. K., Shomorendra M. and Kar D., 2013 - Fish diversity of Pumlen Lake in Manipur with a note on traditional fish catching devices, Indian Journal of applied Research, 3, 10, 46-48.

245. Singh N. R., Singh M. S. and Kar D., 2015a - A check list of fish species diversity of Sone Beel, the biggest wetland in Assam, NeBIO, 6, 1, 21-26.

246. Singh N. R., Das B. K. and Kar D., 2015b - Length-weight relationship (LWR) of Glossogobius giuris (Hamilton-Buchanan, 1822) of Pumlen Lake Thoubal, Manipur, India, International Journal of Environment and Natural Sciences, 5, 1-5.

247. Singh M. S., Singh N. R., Devi I. N., Devi B. D., Ranibala T. and Kar D., 2015c - Check List of fish species of Loktak Lake, Bishnupur District, Biological Forum, 7, 1, 171-179. 
248. Smith G. M., 1950 - The freshwater algae of the United States, McGraw Hill Book Co. Inc. New York, vii +719 .

249. Sonowal M., Kar S., Das B. K., Das S., Singh N. R., Das P., Dutta B. and Kar D., 2015 Preliminary studies on zooplankton diversity of certain wetlands of Southern Assam, Life Science Leaflets, 67, 68-78.

250. Southwell T. and Prashad B., 1918 - On Hilsa investigations in Bengal, Bihar and Orissa, Bulletin of Fishing Department, Bengal, Bihar and Orissa, 15.

251. Sreenivasan A., 1968 - Limnology of tropical impoundments, V, Studies on two upland impoundments in the Nilgiris, Madras State, India, Phykos, 7, 144-160.

252. Steel M. and Penny D., 2010 - Origins of life: common ancestry put to the test, Nature, 465, 7295, 168-169, doi:10.1038/465168a, PMID 20463725.

253. Swingle H. S., 1950 - Relationship and dynamics of balanced and unbalanced fish populations, Bulletin of Alabama Agricultural Experiment Station, 274, 73.

254. Talwar P. K. and Jhingran A. G., 1991 - Inland fishes of India and adjacent countries, I and II, Oxford and IBH Co., Pvt. Ltd., New Delhi, 1158.

255. Toham A. K. and Tuegels G. G., 1998 - Diversity patterns of fish assemblages in the Lower Ntem River basin (Cameroon) with notes on potential effects of deforestation, Archiv für Hydrobiologie, 141, 4, 421-446.

256. Umi N. D., Singh N. R. and Kar D., 2015 - Studies on fish affected with Epizootic Ulcerative Syndrome with special emphasis on parasitic infestation: a project report, Biological Forum, 7, 1, 155-164.

257. Vaas K. F. and Schurman J. J., 1949 - On the ecology and fisheries of some Javanese freshwaters, Common Agriculture Research Station, Buitenzorg Java, 97, 1-60.

258. Welch P. S., 1935 - Limnology, McGraw Hill Book Company, Inc., New York, xiv + 471.

259. Wells H. G., 1922 - A short history of the World ( $1^{\text {st }}$ edit.), New York: Macmillan. Retrieved 1 July 2016 - via Internet Archive, 455.

260. Welch P. S., 2003 - Limnological methods, Narendra Publising House (Indian Edition, New Delhi), xviii + 381 .

261. Wetzel R. G., 1983 - Limnology, Saunders College Publishing, Philadelphia, ix + 858.

262. WCMC, 1996 - Freshwater biodiversity: a preliminary gobal assessment, a document prepared for the $4^{\text {th }}$ meeting of the Conference of the Practices to the Convention of Biological Diversity, World Conservation Monitoring Centre.

263. Zutshi D. P., Wanganeo A. and Raina R., 1970 - Limnology of a man-made lake, Geobios: 30-32. 